Article

\title{
Single and Dual Metal Oxides as Promising Supports for Carbon Monoxide Removal from an Actual Syngas: The Crucial Role of Support on the Selectivity of the Au-Cu System
}

\author{
Bernay Cifuentes ${ }^{1}\left(\mathbb{D}\right.$, Felipe Bustamante ${ }^{2}(\mathbb{D})$ and Martha Cobo ${ }^{1, *} \mathbb{(}$ \\ 1 Energy, Materials, and Environment Laboratory, Chemical Engineering Department, Universidad de La \\ Sabana, Campus Universitario Puente del Común, Km. 7 Autopista Norte, Bogotá 250001, Colombia; \\ bernay.cifuentes1@unisabana.edu.co \\ 2 Environmental Catalysis Research Group, Chemical Engineering Department, Universidad de Antioquia \\ UdeA, Calle 70 No. 52-21, Medellín 050010, Colombia; felipe.bustamante@udea.edu.co \\ * Correspondence: martha.cobo@unisabana.edu.co; Tel.: +571-8615555 (ext. 25207); Fax: +571-8615555
}

Received: 9 September 2019; Accepted: 10 October 2019; Published: 13 October 2019

\begin{abstract}
A catalytic screening was performed to determine the effect of the support on the performance of an $\mathrm{Au}-\mathrm{Cu}$ based system for the removal of $\mathrm{CO}$ from an actual syngas. First, a syngas was obtained from reforming of ethanol. Then, the reformer outlet was connected to a second reactor, where $\mathrm{Au}-\mathrm{Cu}$ catalysts supported on several single and dual metal oxides (i.e., $\mathrm{CeO}_{2}, \mathrm{SiO}_{2}$, $\mathrm{ZrO}_{2}, \mathrm{Al}_{2} \mathrm{O}_{3}, \mathrm{La}_{2} \mathrm{O}_{3}, \mathrm{Fe}_{2} \mathrm{O}_{3}, \mathrm{CeO}_{2}-\mathrm{SiO}_{2}, \mathrm{CeO}_{2}-\mathrm{ZrO}_{2}$, and $\mathrm{CeO}_{2}-\mathrm{Al}_{2} \mathrm{O}_{3}$ ) were evaluated. $\mathrm{AuCu} / \mathrm{CeO}_{2}$ was the most active catalyst due to an elevated oxygen mobility over the surface, promoting $\mathrm{CO}_{2}$ formation from adsorption of $\mathrm{C}-\mathrm{O}^{*}$ and $\mathrm{OH}^{-}$intermediates on $\mathrm{Au}^{0}$ and $\mathrm{CuO}$ species. However, its lower capacity to release the surface oxygen contributes to the generation of stable carbon deposits, which lead to its rapid deactivation. On the other hand, $\mathrm{AuCu} / \mathrm{CeO}_{2}-\mathrm{SiO}_{2}$ was more stable due to its high surface area and lower formation of formate and carbonate intermediates, mitigating carbon deposits. Therefore, use of dual supports could be a promising strategy to overcome the low stability of $\mathrm{AuCu} / \mathrm{CeO}_{2}$. The results of this research are a contribution to integrated production and purification of $\mathrm{H}_{2}$ in a compact system.
\end{abstract}

Keywords: CO-PROX; CO-SMET; $\mathrm{CO}_{2}$ methanation; hydrogen purification; process integration

\section{Introduction}

Synthesis gas (syngas) is used as a chemical building block in the synthesis of commodity chemicals and for energy applications. Specifically, syngas can be used in combustion processes [1], gas turbines [2], or hydrogen fuel cells $\left(\mathrm{H}_{2}-\mathrm{FC}\right)$ [3] to produce energy. $\mathrm{The}_{2}-\mathrm{FC}$ are promising systems to provide sustainable energy for households, industry, transportation, and small devices. Likewise, the use of $\mathrm{H}_{2}-\mathrm{FC}$ has been proposed as an alternative to supply energy in places that are not connected to the electrical network and for remote installations [4].

The syngas composition varies depending on the production source, but mostly contains $\mathrm{H}_{2}$, carbon monoxide (CO), and light hydrocarbons. Bioethanol reforming is one of the most used pathways to produce syngas due to its high yield to $\mathrm{H}_{2}$ [5]. In a previous study [6], we obtained a syngas containing $\mathrm{H}_{2}, \mathrm{CO}, \mathrm{CO}_{2}, \mathrm{CH}_{4}$, and $\mathrm{H}_{2} \mathrm{O}$ from ethanol steam reforming (ESR) using a $\mathrm{RhPt} / \mathrm{CeO}_{2}-\mathrm{SiO}_{2}$ catalyst. Syngas production remained stable for $72 \mathrm{~h}$ of continuous operation and on/off cycles. This syngas could be used for sustainable energy production in $\mathrm{H}_{2}-\mathrm{FC}$. However, $\mathrm{CO}$ must be removed from the syngas because of its harmful effect on fuel cell electrodes [7]. 
One of the most used strategies of CO removal from syngas is via chemical pathways, which includes preferential oxidation of CO (CO-PROX) [8,9], water gas shift reaction (WGSR) [10], and selective CO methanation (CO-SMET) [10]. Traditionally, the objective of the CO cleanup step is to ensure $\mathrm{CO}$ concentrations below $10 \mathrm{ppm}$, which requires several catalytic reactors in series [11] and presents a high operating cost. However, recent research studies have allowed the development of $\mathrm{H}_{2}$-FC systems that tolerate $\mathrm{CO}$ concentrations above $100 \mathrm{ppm}$ [12-14]. These contributions facilitate the use of less complex systems for syngas purification, which could lead to the development of more compact and economic $\mathrm{H}_{2}$ technology.

Anticipating the commercialization of a new generation of more CO-tolerant $\mathrm{H}_{2}-\mathrm{FC}$, it has been proposed to redesign the $\mathrm{CO}$ removal stage to reduce the number of process units in syngas purification. The new approach seeks to carry out CO removal using a single catalytic reactor, where several reactions occur simultaneously (i.e., CO-PROX, WGSR, and CO-SMET). Kugai et al. [15] studied Pt-Cu and $\mathrm{Pd}-\mathrm{Cu}$ bimetallic catalysts supported on $\mathrm{CeO}_{2}$ for oxygen-enhanced water gas shift (OWGS), where WGSR and CO-PROX occur concurrently, reporting higher CO removal from a model reformate gas (synthetic syngas) in the OWGS compared to the WGSR carried out individually. Similarly, $\mathrm{Xu}$ and Zhang [16] reported that the presence of CO-SMET during CO-PROX on a commercial $\mathrm{Ru} / \mathrm{Al}_{2} \mathrm{O}_{3}$ catalyst allows for wider temperature windows that ensure the $\mathrm{CO}$ removal of a synthetic syngas. Despite these valuable contributions, the CO removal from syngas in a compact system is still at laboratory scale. Among the limitations for evaluation at the pilot scale is the lack of consensus regarding the catalyst and the most appropriate operating conditions to carry out the syngas purification.

$\mathrm{Au}$ is recognized as a promising catalyst in the three cleaning reactions of syngas (i.e., CO-PROX, WGSR, and CO-SMET) [17,18]. Reina et al. [19] evaluated bimetallic catalysts of $\mathrm{Au}-\mathrm{M}(\mathrm{M}=\mathrm{La}, \mathrm{Ni}$, $\mathrm{Cu}, \mathrm{Fe}, \mathrm{Cr}, \mathrm{Y})$, reporting that $\mathrm{CO}$ oxidation is favored by the $\mathrm{Au}-\mathrm{Cu}$ combination because $\mathrm{Cu}$ interacts strongly with the support, favoring the oxygen mobility in the catalyst. Also, in a previous study [20], we evaluated $\mathrm{Au}-\mathrm{Cu}$ bimetallic catalysts supported on $\mathrm{CeO}_{2}$ for $\mathrm{CO}$ removal from a syngas obtained from ESR. It was possible to reduce the CO concentration below $100 \mathrm{ppm}$, but the catalyst showed rapid deactivation after $40 \mathrm{~h}$. Deactivation was related to structural changes in the support and to the accumulation of carbonaceous compounds during continuous operation. Thus, this study illustrated that the support plays a key role in CO removal from an actual syngas, and led us to evaluate different supports for $\mathrm{CO}$ removal from a syngas in the search for a stable material.

Figure 1 shows the supports most used in the $\mathrm{CO}$ removal processes (i.e., WGSR, CO-PROX, CO-SMET, or their combinations). $\mathrm{CeO}_{2}, \mathrm{Fe}_{2} \mathrm{O}_{3}, \mathrm{ZrO}_{2}, \mathrm{TiO}_{2}$, and $\mathrm{Al}_{2} \mathrm{O}_{3}$ are the most commonly used single supports in $\mathrm{CO}$ removal from synthetic syngas. However, there is a growing interest in mixed supports (dual metal oxides), because they may have characteristics not observed in individual supports [21]. Most combinations of dual metal oxides include $\mathrm{CeO}_{2}$ in the matrix, usually combined with supports that provide larger surface area, such as $\mathrm{Al}_{2} \mathrm{O}_{3}$ [22] and $\mathrm{SiO}_{2}$ [23], or with basic oxides, such as $\mathrm{ZrO}_{2}$, to generate new active sites [24]. $\mathrm{TiO}_{2}$ is mainly used in $\mathrm{CO}$ removal by photocatalytic processes [25] and was not considered in this study. On the other hand, although $\mathrm{La}_{2} \mathrm{O}_{3}$ is not among the most used supports in $\mathrm{CO}$ removal, it was recently reported that $\mathrm{La}_{2} \mathrm{O}_{3}$ is effective for avoiding carbon deposits during CO-SMET [26]. 


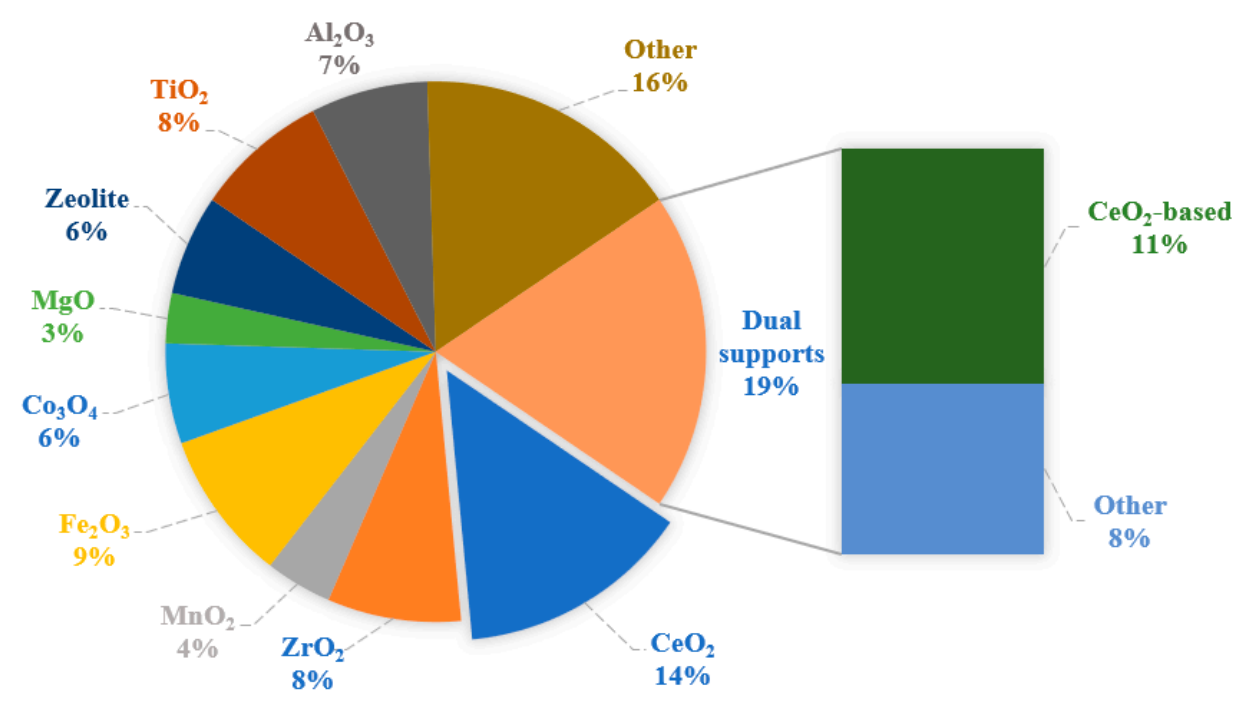

Figure 1. Supports used in CO removal from syngas streams using CO-PROX, WGSR or CO-SMET reactions.

Although several supports for syngas cleanup have been proposed, each investigation was carried out under different experimental conditions and using synthetic syngas, which makes it difficult to select the most suitable support for the CO removal. Therefore, the objective of this work was to study the $\mathrm{CO}$ removal from an actual syngas using bimetallic catalysts of $\mathrm{AuCu}$-supported on single and dual metal oxides. Specifically, $\mathrm{CeO}_{2}, \mathrm{ZrO}_{2}, \mathrm{La}_{2} \mathrm{O}_{3}, \mathrm{Fe}_{2} \mathrm{O}_{3}, \mathrm{Al}_{2} \mathrm{O}_{3}$, and $\mathrm{SiO}_{2}$ were selected as single metal oxides, and $\mathrm{CeO}_{2}-\mathrm{SiO}_{2}, \mathrm{CeO}_{2}-\mathrm{ZrO}_{2}$, and $\mathrm{CeO}_{2}-\mathrm{Al}_{2} \mathrm{O}_{3}$ as dual metal oxides. The catalytic performance of the supports with and without active metals (i.e., $\mathrm{Au}$ and $\mathrm{Cu}$ ) was evaluated. Then, the activity, selectivity, and stability were established as criteria for selecting the most suitable support for the $\mathrm{CO}$ elimination. In addition, characterization tests were conducted, such as temperature programmed reduction (TPR), surface area tests using the Brunauer-Emmett-Teller (BET) method, oxygen storage capacity (OSC) tests, thermogravimetric analysis (TGA), and in situ diffuse reflectance infrared Fourier transform spectroscopy (DRIFTS).

\section{Results and Discussion}

\subsection{Activity, Selectivity, and Stability}

Figure 2 shows the $\mathrm{CO}$ conversion in the cleanup reactor on the bare supports (i.e., without $\mathrm{Au}$ and $\mathrm{Cu}$ ) and $\mathrm{Au}-\mathrm{Cu}$-supported catalysts. $\mathrm{CeO}_{2}$ and $\mathrm{ZrO}_{2}$ display the larger $\mathrm{CO}$ conversion between single metal oxides (Figure 2a). Indeed, the presence of oxygen vacancies on the surface of an oxide could favor a support showing high activity in the $\mathrm{CO}$ oxidation, despite the absence of active metals [27]; on the other hand, supports with low OSC, such as $\mathrm{Al}_{2} \mathrm{O}_{3}$ [28], present lower activity. The use of dual metal oxides has been proposed as a strategy to overcome the deficiencies of single supports [21]. Figure $2 \mathrm{~b}$ shows that $\mathrm{CeO}_{2}-\mathrm{SiO}_{2}$ increases the $\mathrm{CO}$ conversion compared to $\mathrm{SiO}_{2}$, which could be associated with the interaction between the two oxides. However, no significant improvement in the $\mathrm{CO}$ conversion with $\mathrm{CeO}_{2}-\mathrm{Al}_{2} \mathrm{O}_{3}$ was observed, and even for $\mathrm{CeO}_{2}-\mathrm{ZrO}_{2}$, the combination of the two metal oxides leads to a less active material. Furthermore, below $260^{\circ} \mathrm{C}$ the dual metal oxides showed less activity that single $\mathrm{CeO}_{2}$, suggesting that the combination of several metal oxides does not always lead to more active materials in the syngas cleaning. 

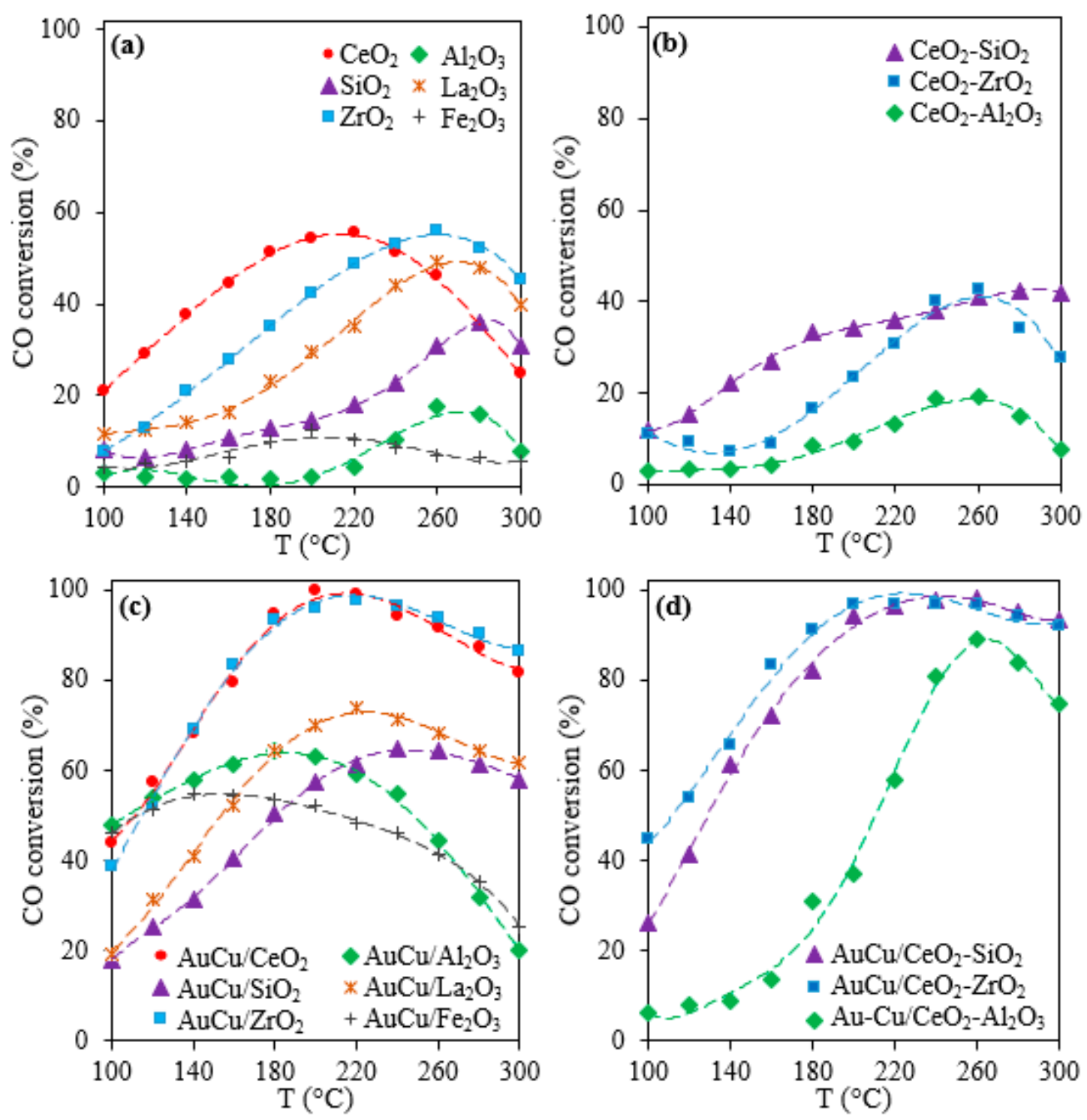

Figure 2. CO conversion obtained in the Cleanup reactor with supports (a,b) and supported $1 \mathrm{wt} \%$ $\mathrm{Au}-1 \mathrm{wt} \% \mathrm{Cu}$ catalysts (c,d). Syngas feed: $7.8 \% \mathrm{H}_{2}, 2.0 \% \mathrm{CO}, 0.5 \% \mathrm{CO}_{2}, 0.3 \% \mathrm{CH}_{4}, 1.4 \% \mathrm{H}_{2} \mathrm{O}, 1.8 \% \mathrm{O}_{2}$, $6.8 \% \mathrm{~N}_{2}$, and $79.4 \%$ Ar. Reaction conditions: Space velocity $(\mathrm{SV})=6.5 \pm 0.2 \mathrm{~L} / \mathrm{g}_{\text {cat }}{ }^{*} \mathrm{~min}$ and $0.3 \mathrm{~g}$ of the catalytic bed.

On the other hand, catalytic systems based on $\mathrm{Au}, \mathrm{Cu}$ and $\mathrm{Au}-\mathrm{Cu}$ have been studied extensively for the CO oxidation, CO-PROX, WGSR, and CO-SMET. In-depth descriptions for $\mathrm{Cu} / \mathrm{CeO}_{2}$ [9], $\mathrm{AuCu} / \mathrm{CeO}_{2}$ [29], $\mathrm{AuCu} / \mathrm{SiO}_{2}$ [30], $\mathrm{AuCu} / \mathrm{Al}_{2} \mathrm{O}_{3}$ [31], $\mathrm{Au} / \mathrm{Fe}_{2} \mathrm{O}_{3}$ [32], $\mathrm{Au} / \mathrm{La}_{2} \mathrm{O}_{3} / \mathrm{Al}_{2} \mathrm{O}_{3}$ [33], and $\mathrm{Au} / \mathrm{CeO}_{2}-\mathrm{ZrO}_{2}[34,35]$ are available in the literature. In general, $\mathrm{Au}$ favors the $\mathrm{CO}$ conversion through a mechanism that involves $\mathrm{Au}-\mathrm{CO}$ and $\mathrm{Au}-\mathrm{OOH}$ species [36], where the formation of $\mathrm{C}-\mathrm{O}^{*}$ intermediates determines the selectivity of the process [20], while $\mathrm{CuO}$ acts through a redox mechanism [8], promoting oxygen mobility in the oxide lattice [37] and facilitating the CO oxidation. A synergistic $\mathrm{Au}-\mathrm{Cu}$ effect has also been proposed $[19,29,38]$. Therefore, the inclusion of $1 \mathrm{wt} \% \mathrm{Au}$ and $1 \mathrm{wt} \% \mathrm{Cu}$ in the single and dual metal oxides promotes greater CO conversion (Figure 2). Despite having the same active metals (i.e., $\mathrm{Au}$ and $\mathrm{Cu}$ ), the catalysts showed maximum $\mathrm{CO}$ conversion at different temperatures, indicating that the properties of the support have a key role in the syngas cleaning. Table 1 shows that only $\mathrm{AuCu} / \mathrm{CeO}_{2}$ reached $\mathrm{CO}$ concentrations below $100 \mathrm{ppm}$ in the actual syngas at $210^{\circ} \mathrm{C}$, whereas minimum $\mathrm{CO}$ concentrations of the other catalysts were above $500 \mathrm{ppm}$. 
Table 1. Minimum concentration of CO obtained in syngas, apparent active metal dispersion ( $\mathrm{H} / \mathrm{M}$ ratio), surface area, OSC, and OSCC of Au-Cu catalysts supported on single and dual supports.

\begin{tabular}{|c|c|c|c|c|c|c|c|c|}
\hline \multirow[t]{2}{*}{ Catalyst $^{\mathrm{a}}$} & \multirow{2}{*}{$\begin{array}{c}\text { Minimum CO } \\
\text { Concentration in } \\
\text { Outlet Gas }(\mathrm{ppm})^{\mathrm{b}}\end{array}$} & \multirow{2}{*}{$\begin{array}{l}\mathrm{H} / \mathrm{M} \\
\text { Index }\end{array}$} & \multicolumn{2}{|c|}{$\begin{array}{c}\text { BET Surface } \\
\text { Area }\left(\mathrm{m}^{2} / \mathrm{g}_{\mathrm{cat}}\right)\end{array}$} & \multicolumn{2}{|c|}{$\begin{array}{l}\text { OSC in AC Samples } \\
\left(\mu \mathrm{mol} \mathrm{O}_{2} / \mathrm{g}_{\mathrm{cat}}\right)\end{array}$} & \multicolumn{2}{|c|}{$\begin{array}{c}\text { OSCC at } 300{ }^{\circ} \mathrm{C} \\
\left(\mu \mathrm{mol} \mathrm{O}_{2} / \mathrm{g}_{\mathrm{cat}}\right)\end{array}$} \\
\hline & & & AC & Spent & $100^{\circ} \mathrm{C}$ & $300^{\circ} \mathrm{C}$ & Fresh & Spent \\
\hline $\mathrm{AuCu} / \mathrm{CeO}_{2}$ & 75 at $210^{\circ} \mathrm{C}$ & 0.9 & 60 & $\begin{array}{l}58(\mathrm{U}) \\
50(\mathrm{~S})\end{array}$ & 41 & 91 & 230 & $\begin{array}{c}121(\mathrm{U}) \\
93(\mathrm{~S})\end{array}$ \\
\hline $\mathrm{AuCu} / \mathrm{SiO}_{2}$ & 8320 at $240^{\circ} \mathrm{C}$ & 0.7 & 364 & $277(\mathrm{U})$ & 21 & 37 & 45 & $41(\mathrm{U})$ \\
\hline $\mathrm{AuCu} / \mathrm{ZrO}_{2}$ & 507 at $225^{\circ} \mathrm{C}$ & 0.8 & 58 & $47(\mathrm{U})$ & 39 & 76 & 185 & $84(\mathrm{U})$ \\
\hline $\mathrm{AuCu} / \mathrm{Al}_{2} \mathrm{O}_{3}$ & 745 at $180^{\circ} \mathrm{C}$ & 0.8 & 90 & $65(\mathrm{U})$ & 31 & 35 & 75 & $41(\mathrm{U})$ \\
\hline $\mathrm{AuCu} / \mathrm{La}_{2} \mathrm{O}_{3}$ & 5365 at $225^{\circ} \mathrm{C}$ & 0.4 & 19 & $18(\mathrm{U})$ & 21 & 41 & 90 & $24(\mathrm{U})$ \\
\hline $\mathrm{AuCu} / \mathrm{Fe}_{2} \mathrm{O}_{3}$ & 9416 at $140{ }^{\circ} \mathrm{C}$ & 0.4 & 16 & $5(\mathrm{U})$ & NR & NR & NR & NR \\
\hline $\mathrm{AuCu} / \mathrm{CeO}_{2}-\mathrm{SiO}_{2}$ & 861 at $230^{\circ} \mathrm{C}$ & 1.6 & 110 & $\begin{array}{l}75(\mathrm{U}) \\
74(\mathrm{~S})\end{array}$ & 34 & 78 & 146 & $\begin{array}{l}121(\mathrm{U}) \\
126(\mathrm{~S})\end{array}$ \\
\hline $\mathrm{AuCu} / \mathrm{CeO}_{2}-\mathrm{ZrO}_{2}$ & 941 at $210^{\circ} \mathrm{C}$ & 0.9 & 42 & $30(\mathrm{U})$ & 42 & 94 & 210 & $162(\mathrm{U})$ \\
\hline $\mathrm{AuCu} / \mathrm{CeO}_{2}-\mathrm{Al}_{2} \mathrm{O}_{3}$ & 31521 at $260^{\circ} \mathrm{C}$ & 1.2 & 65 & $56(\mathrm{U})$ & 32 & 79 & 155 & $121(\mathrm{U})$ \\
\hline
\end{tabular}

a Nominal metal loadings: $1 \mathrm{wt} \% \mathrm{Au}$ and $1 \mathrm{wt} \% \mathrm{Cu} .{ }^{\mathrm{b}}$ Value includes the carrier gas. AC: activated catalyst, which were reduced with $\mathrm{H}_{2}$ and stabilized in air before activity tests. U: sample used to obtain light-off curves. S: sample evaluated in the stability test. Note: $\mathrm{NR}=$ Not reported; $\mathrm{OSC}=$ oxygen storage capacity; OSCC $=$ oxygen storage complete capacity; BET: Brunauer-Emmett-Teller test.

On the other hand, the selectivity in the CO removal has been attributed to the support rather than the active metal [39], being the consumption of $\mathrm{H}_{2}$ an important criterion in catalyst selection [39]. Figure 3 shows that $\mathrm{H}_{2}$ consumption increases with temperature, particularly in the supports and catalysts based on $\mathrm{ZrO}_{2}$. The deficiency of $\mathrm{ZrO}_{2}$ to adsorb/desorb bidentate carbonates above $150^{\circ} \mathrm{C}$ has been associated with a promotion of the $\mathrm{H}_{2}$ combustion over the $\mathrm{CO}$ oxidation [40]. Likewise, $\mathrm{H}_{2}$ loss increases in the majority of the supported $\mathrm{Au}-\mathrm{Cu}$ catalysts (Figure 3c,d) compared to their respective bare support (Figure 3a,b), possibly due to affinity of the $\mathrm{Au}-\mathrm{Cu}$ system to form intermediates in the $\mathrm{H}_{2}$ oxidation (e.g., hydroxyl groups [29,41]) and methane formation (e.g., C-O* species [18,20,42]). Also, the most active catalysts in the $\mathrm{CO}$ removal (i.e., $\mathrm{AuCu} / \mathrm{CeO}{ }_{2}, \mathrm{AuCu} / \mathrm{ZrO} 2, \mathrm{AuCu} / \mathrm{CeO}_{2}-\mathrm{SiO}_{2}$, and $\mathrm{AuCu} / \mathrm{CeO}_{2}-\mathrm{ZrO}_{2}$ ) promote higher $\mathrm{H}_{2}$ consumption. That is, an active catalyst in the $\mathrm{CO}$ conversion possibly has an inherent tendency to consume $\mathrm{H}_{2}$. The high $\mathrm{H}_{2}$ consumption, which in some cases exceeds $20 \%$, could be associated with the syngas composition [20,37], specifically with the $\mathrm{H}_{2} / \mathrm{CO}$ ratio. Table 2 shows the results obtained in the $\mathrm{CO}$ removal with catalytic systems based on $\mathrm{Au}-\mathrm{Cu}$. High $\mathrm{H}_{2} / \mathrm{CO}$ ratios (>>10 [43]) are used in CO-PROX with synthetic syngas to favor CO oxidation [44] and reduce the $\mathrm{H}_{2}$ consumption. To achieve such high $\mathrm{H}_{2} / \mathrm{CO}$ ratios before CO-PROX several WGSR reactors are required, however [11]. Thence, aiming at reducing the number of units used in the traditional process, it has been proposed to carry out $\mathrm{CO}$ removal reactions in a single reactor using the syngas that comes directly from the reformer $[15,20,35]$. Nevertheless, the syngas obtained directly from the ESR contains larger amounts of $\mathrm{CO} . \mathrm{H}_{2} / \mathrm{CO}$ ratios around 4 have been reported for syngas obtained from ESR using $\mathrm{Ir} / \mathrm{CeO}_{2}$ [45] and $\mathrm{RhPd} / \mathrm{CeO}_{2}$ [46] catalysts. Thus, the low $\mathrm{H}_{2} / \mathrm{CO}$ ratio in the actual syngas (e.g., the syngas used in this work has an $\mathrm{H}_{2} / \mathrm{CO}=4$ ) could conduce to a high $\mathrm{H}_{2}$ loss in the cleanup reactor. Simultaneous production of $\mathrm{CO}_{2}$ and $\mathrm{CH}_{4}$ was observed in all catalysts evaluated (Figures A1 and A2 in Appendix A), suggesting that CO-SMET and $\mathrm{CO}_{2}$ methanation occur together with CO-PROX and WGSR. Then, $\mathrm{H}_{2}$ oxidation and carbon hydrogenation would be the main causes of $\mathrm{H}_{2}$ loss during the $\mathrm{CO}$ removal from an actual syngas. 

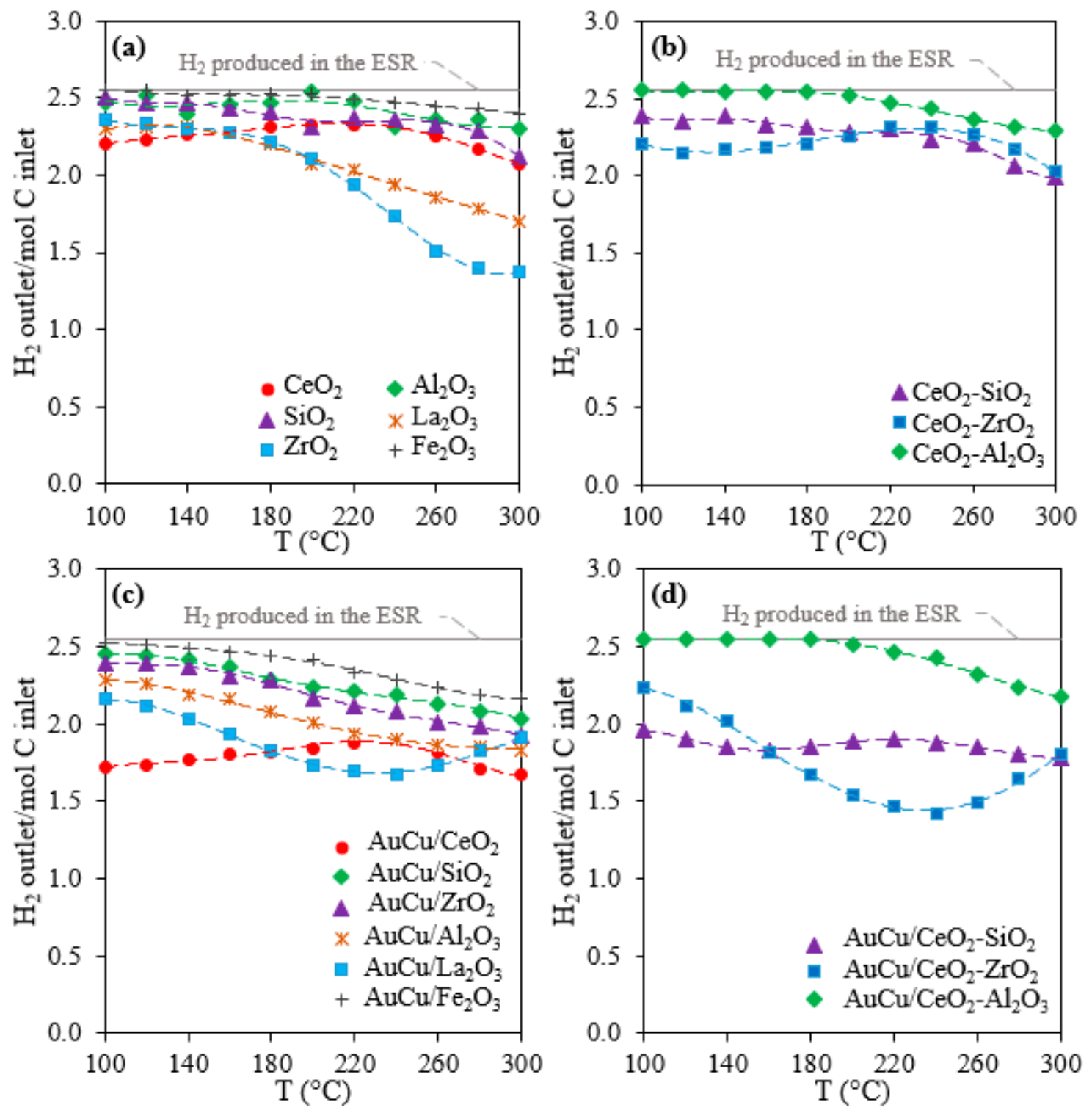

Figure 3. $\mathrm{H}_{2}$ yield obtained from a system that integrate the ethanol steam reforming (ESR) reactor and the cleanup reactor, where the CO removal is performed with bare supports $(\mathbf{a}, \mathbf{b})$ and supported $1 \mathrm{wt} \%$ $\mathrm{Au}-1 \mathrm{wt} \% \mathrm{Cu}$ catalysts $(\mathbf{c}, \mathbf{d})$. Reaction conditions: $\mathrm{SV}=6.5 \pm 0.2 \mathrm{~L} / \mathrm{g}_{\mathrm{cat}}{ }^{*} \mathrm{~min}$ and $0.3 \mathrm{~g}$ of the catalytic bed in both reactors.

Table 2. Comparison of various catalytic systems for the $\mathrm{CO}$ removal using $\mathrm{Au}-\mathrm{Cu}$ catalysts.

\begin{tabular}{ccccccc}
\hline Catalyst & $\begin{array}{c}\text { Syngas } \\
\text { Type }\end{array}$ & $\mathbf{H}_{2} / \mathbf{C O}$ & $\mathbf{T}\left({ }^{\circ} \mathbf{C}\right)$ & $\begin{array}{c}\text { CO Conversion } \\
\text { (\%) }\end{array}$ & $\mathbf{H}_{\mathbf{2}}$ Loss (\%) & Ref. \\
\hline $\mathrm{AuCu} / \mathrm{CeO}_{2}$ & Synthetic & 30 & 220 & 90 & 2 & {$[29]$} \\
$\mathrm{AuCu} / \mathrm{SBA}-15$ & Synthetic & $>50$ & 25 & 100 & $5^{\mathrm{a}}$ & {$[47]$} \\
$\mathrm{Au} / \mathrm{CuO}-\mathrm{CeO}_{2} / \mathrm{Al}_{2} \mathrm{O}_{3}$ & Synthetic & 4.5 & 350 & 75 & $\mathrm{NR}$ & {$[17]$} \\
$\mathrm{Au} / \mathrm{CeO}{ }_{2}-\mathrm{CuO}_{2} / \mathrm{Al}_{2} \mathrm{O}_{3}$ & Synthetic & 50 & 110 & 95 & $3^{\mathrm{a}}$ & {$[19]$} \\
$\mathrm{Au} / \mathrm{Al}_{2} \mathrm{O}_{3}$ & Synthetic & $>50$ & 80 & 99 & $2^{\mathrm{a}}$ & {$[36]$} \\
$\mathrm{Au} / \mathrm{CeO}_{2}-\mathrm{ZrO}_{2}$ & Actual & 30 & 100 & 99 & $22^{\mathrm{a}}$ & {$[35]$} \\
$\mathrm{AuCu} / \mathrm{CeO}_{2}$ & Actual & 4 & 210 & 99 & 17 & This work \\
$\mathrm{AuCu} / \mathrm{CeO}_{2}-\mathrm{SiO}_{2}$ & Actual & 4 & 230 & 97 & 19 & This work \\
\hline
\end{tabular}


Although $\mathrm{CH}_{4}$ formation implicitly involves an undesirable $\mathrm{H}_{2}$ consumption, it has been reported that a combination of CO-PROX and methanation improves $\mathrm{CO}$ removal compared to the CO-PROX alone, because of favoritism in the activation of adsorbed $\mathrm{CO}$ [16]. Then, $\mathrm{C}$ and $\mathrm{H}$ mass balances were carried out to determine the effect of $\mathrm{CH}_{4}$ production on $\mathrm{H}_{2}$ consumption and $\mathrm{CO}$ conversion. Figure 4 shows the $\mathrm{H}_{2}$ and $\mathrm{CO}$ converted with respect to the $\mathrm{CH}_{4}$ formed in the cleanup reactor. $\mathrm{CH}_{4}$ formation appears to be directly proportional to $\mathrm{H}_{2}$ loss (Figure $4 \mathrm{a}$ ), but the amount of $\mathrm{H}_{2}$ consumed is larger than the amount of $\mathrm{H}_{2}$ contained in the formed $\mathrm{CH}_{4}$ (yellow line); moreover, in most catalysts, $\mathrm{H}_{2}$ loss is larger than the $\mathrm{H}_{2}$ required by $\mathrm{CO}_{2}$ methanation (green line). Hence, the remnant of $\mathrm{H}_{2}$ loss may be associated with the production of water or hydrogenated compounds not detected by GC, indicating that methanation would have a secondary role in the $\mathrm{H}_{2}$ loss during the syngas cleanup. On the other hand, $\mathrm{CO}$ conversion grows faster compared to the contribution of methanation (Figure $4 \mathrm{~b}$ ). $\mathrm{Xu}$ et al. [16] studied a $\mathrm{Rh} / \mathrm{Al}_{2} \mathrm{O}_{3}$ catalyst and proposed that at temperatures above $150^{\circ} \mathrm{C}$, the methanation of $\mathrm{CO}_{2}$ formed during the CO-PROX facilitates the $\mathrm{CO}$ oxidation caused by changes in the $\mathrm{C}-\mathrm{O}^{*}$ and $\mathrm{H}^{*}$ adsorbed species. This possible beneficial effect of CO-PROX and subsequent $\mathrm{CO}_{2}$ methanation seems to be stronger in some catalysts (e.g., $\mathrm{AuCu} / \mathrm{CeO}_{2}-\mathrm{Al}_{2} \mathrm{O}_{3}$ and $\mathrm{AuCu} / \mathrm{CeO}_{2}-\mathrm{SiO}_{2}$ ), which would explain their higher activity at high temperatures (Figure 2d), where most $\mathrm{CH}_{4}$ was produced (Figure A2 in Appendix A). $\mathrm{AuCu} / \mathrm{CeO}_{2}$ and $\mathrm{AuCu} / \mathrm{La}_{2} \mathrm{O}_{3}$ show an atypical trend (Figure $4 \mathrm{~b}$ ), where the $\mathrm{CO}$ conversion decreases with the $\mathrm{CH}_{4}$ formation, which could depend on the intermediates of $\mathrm{C}-\mathrm{O}^{*}$ formed on theses catalysts, as will be discussed later. Therefore, these results would confirm the beneficial effect of $\mathrm{CO}_{2}$ methanation during the CO-PROX proposed in [16], but it was also identified that this effect depends on the support and composition of the syngas.
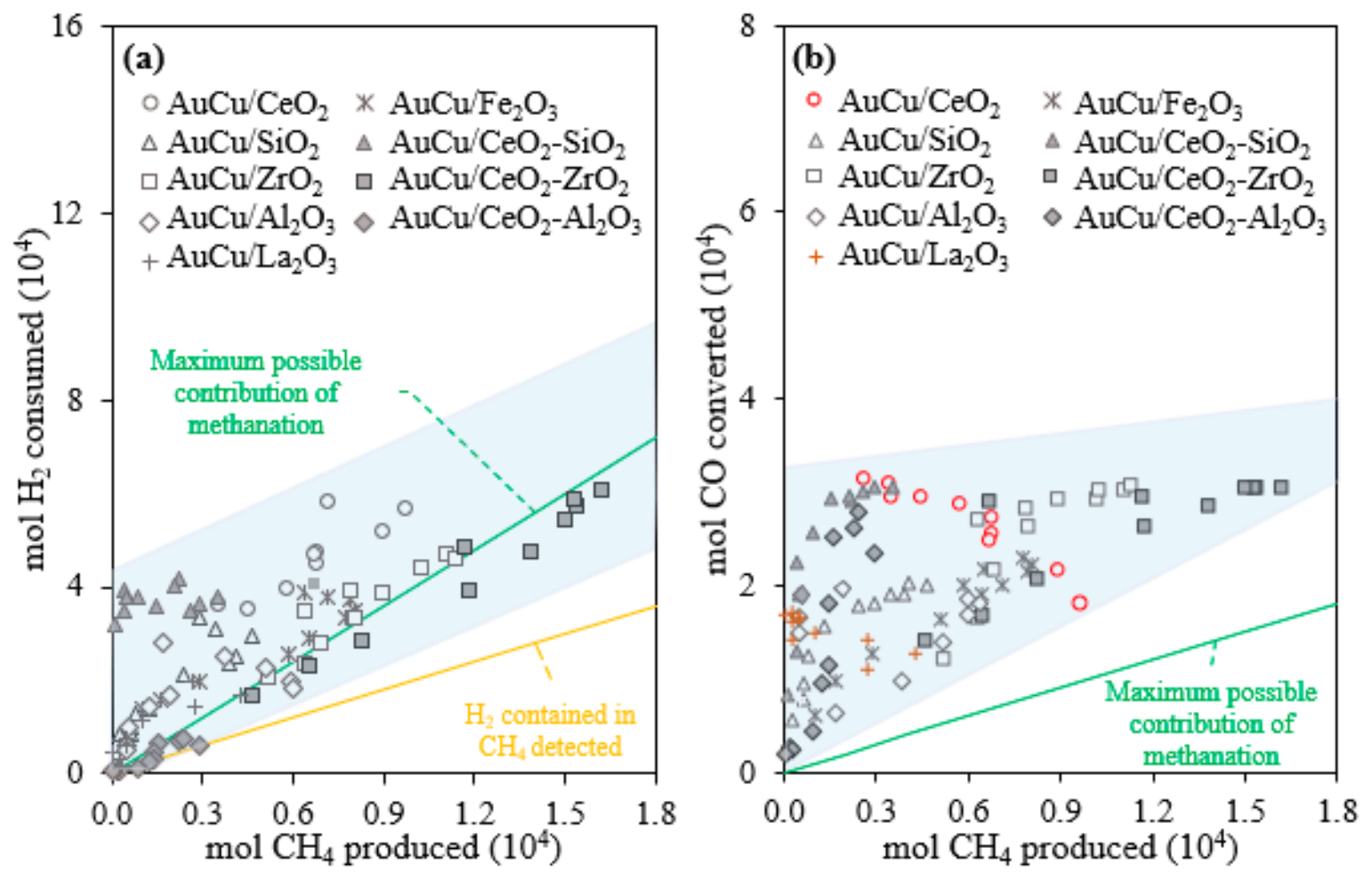

Figure 4. Contribution of methanation in (a) the $\mathrm{H}_{2}$ consumption and (b) $\mathrm{CO}$ conversion during the $\mathrm{CO}$ removal from an actual syngas. The shaded area conveys the trend of the experimental data.

Although the main objective in the cleaning of the syngas is the CO removal, differences in the activity and selectivity could lead to changes in product distribution over prolonged periods of operation. Therefore, the stability of $\mathrm{Au}-\mathrm{Cu}$ catalysts loaded on the best single $\left(\mathrm{CeO}_{2}\right)$ and dual support $\left(\mathrm{CeO}_{2}-\mathrm{SiO}_{2}\right)$ was evaluated. Figure 5 shows the product distribution over time obtained from a system consisting of ESR and cleanup reactors, the latter of which is packed with either 
$\mathrm{AuCu} / \mathrm{CeO}_{2}$ or $\mathrm{AuCu} / \mathrm{CeO}_{2}-\mathrm{SiO}_{2}$. In both cases, a $\mathrm{H}_{2}$-rich stream is obtained. However, $\mathrm{AuCu} / \mathrm{CeO} 2$ shows more variability in product distribution, and after around $42 \mathrm{~h}$ of operation deactivation was observed, at which point the test was stopped. In contrast, the $\mathrm{AuCu} / \mathrm{CeO}_{2}-\mathrm{SiO}_{2}$ catalyst ensures a stable operation for longer periods of time (at least 30\% more time-on-stream, Figure $5 \mathrm{~b}$ ) with CO concentration of about $1000 \mathrm{ppm}$. The results of the stability test show that the use of dual metal oxides leads to less active (i.e., $\mathrm{CO}$ concentration of $1000 \mathrm{ppm}$ versus $75 \mathrm{ppm}$ ) but more stable materials, which could be more interesting in extended processes.
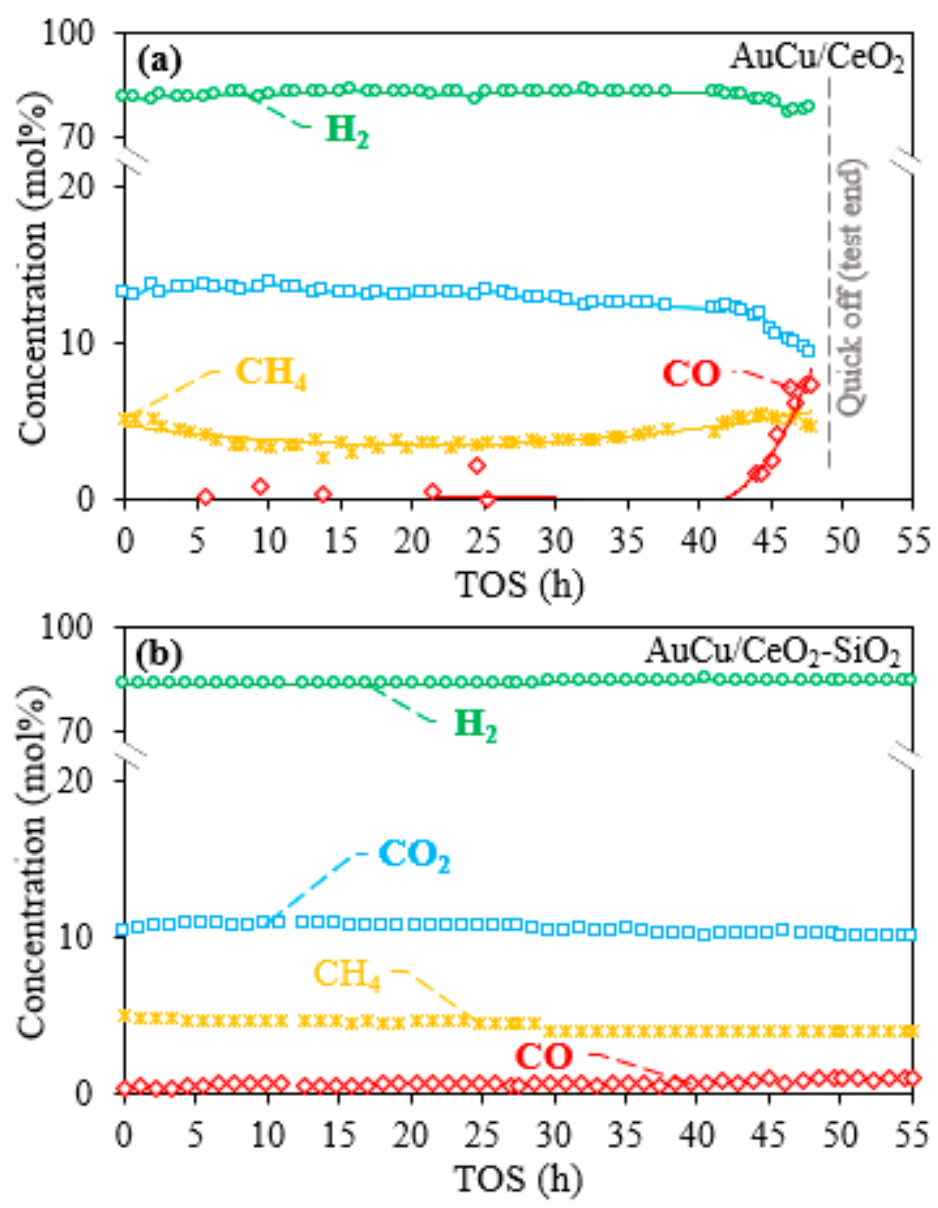

Figure 5. Products distribution obtained from a system that integrate the ESR reactor and the cleanup reactor, where the $\mathrm{CO}$ removal is performed with (a) $\mathrm{AuCu} / \mathrm{CeO}$ and (b) $\mathrm{AuCu} / \mathrm{CeO}{ }_{2}-\mathrm{SiO}_{2}$ catalysts. Syngas feed: $7.8 \% \mathrm{H}_{2}, 2.0 \% \mathrm{CO}, 0.5 \% \mathrm{CO}_{2}, 0.3 \% \mathrm{CH}_{4}, 1.4 \% \mathrm{H}_{2} \mathrm{O}, 1.8 \% \mathrm{O}_{2}, 6.8 \% \mathrm{~N}_{2}$, and $79.4 \%$ Ar. Reaction conditions: The space velocity $(\mathrm{SV})=6.5 \pm 0.2 \mathrm{~L} / \mathrm{g}_{\mathrm{cat}}{ }^{*} \mathrm{~min}$ and $0.3 \mathrm{~g}$ of the catalytic bed. Note: TOS $=$ Time-on-stream

Activity, $\mathrm{H}_{2}$ consumption, and stability were used as criteria for comparison among the $\mathrm{Au}-\mathrm{Cu}$-supported catalysts for the $\mathrm{CO}$ removal from an actual syngas. Now, catalytic properties, such as reducibility, surface area, OSC, carbon deposit formation, and the CO-support interactions, will be related to the activity, selectivity, and stability of the $\mathrm{Au}-\mathrm{Cu}$ catalysts supported in single and dual metal oxides.

\subsection{Catalysts Characterization}

\subsubsection{TPR}

The redox properties of catalysts have a significant effect on $\mathrm{CO}$ oxidation and metal-support interactions [17]. Figure 6 shows the $\mathrm{H}_{2}$-TPR profiles for the $\mathrm{Au}-\mathrm{Cu}$ catalysts supported on single and 
dual metal oxides. Deconvolution peaks are presented to identify possible individual contributions in each reduction zone, but they are not intended to be exact. Contrary to bare supports (Figure A3 in Appendix A), discrepancies are observed between supported $\mathrm{Au}-\mathrm{Cu}$ catalysts. The specific reduction temperatures for $\mathrm{Au}$ and $\mathrm{Cu}$ are very diverse in the literature, possibly because the reduction of metals strongly depends on the interaction with other species [48]. In this study, a first zone $\left(<130^{\circ} \mathrm{C}\right)$ observed was attributed to the reduction of $\mathrm{Au}^{3+}$ and $\mathrm{Au}^{+}$nanoparticles [41]. The second zone (130 to $430{ }^{\circ} \mathrm{C}$ ) was associated with the reduction of $\mathrm{Cu}$, where at least three species [49] can be identified: $(\alpha)$ easily reducible $\mathrm{CuO}$ nano particles, $(\beta)$ particles of $\mathrm{CuO}$ dispersed that interact moderately with the support, and $(\gamma)$ isolated particles of $\mathrm{Cu}[50]$. In the last zone $\left(>430^{\circ} \mathrm{C}\right)$, the reduction of surface layers and bulk of the support is likely happening [34]. The $\alpha$ and $\beta$ species promote the formation of oxygen vacancies [51], contributing to the $\mathrm{CO}$ oxidation. Thus, preferential formation of $\mathrm{CuO}$ species in single and dual metal supports would explain the increase in $\mathrm{CO}_{2}$ production over $\mathrm{Au}-\mathrm{Cu}$-supported catalysts compared to bare supports (Figures A1 and A2 in Appendix A).
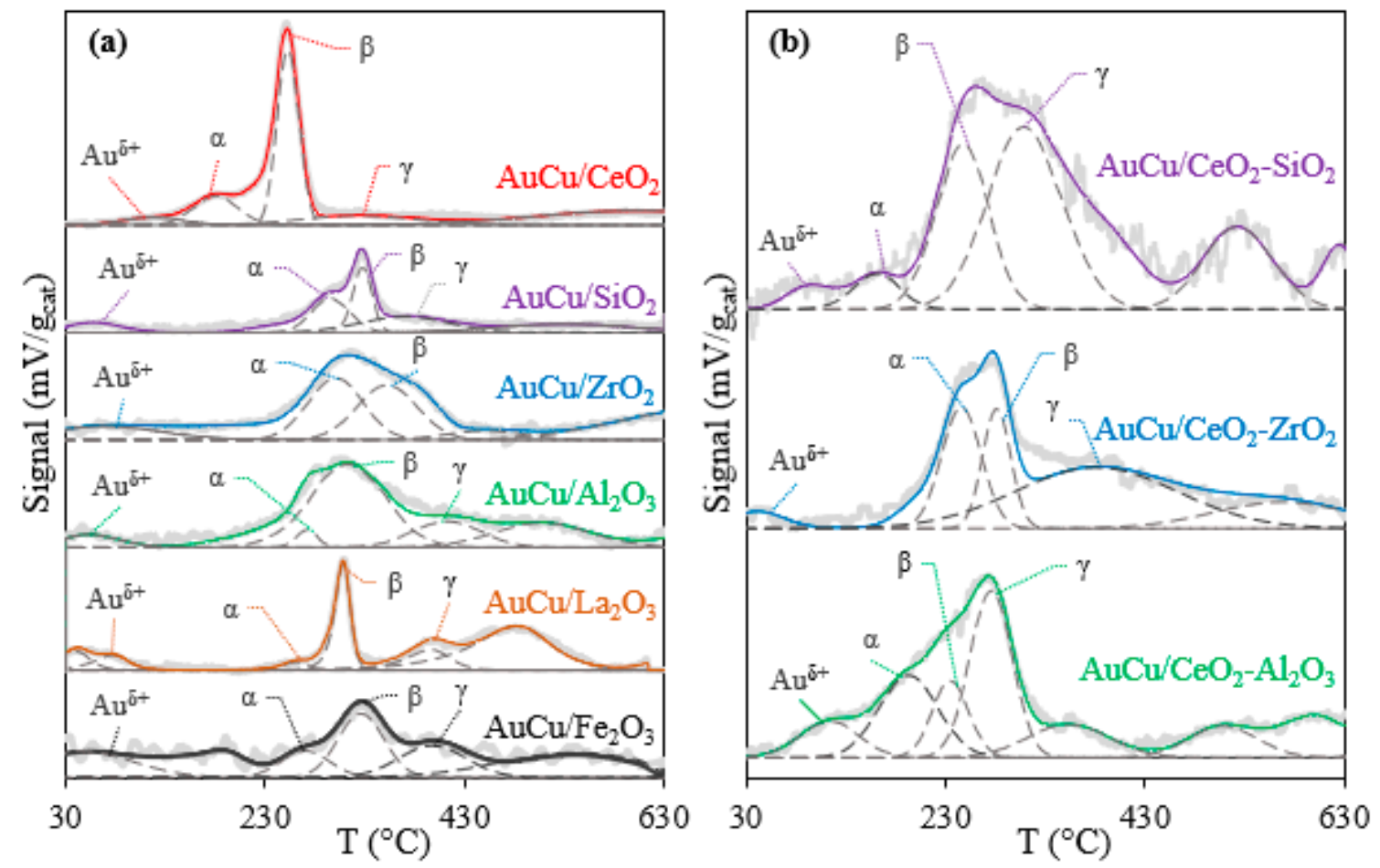

Figure 6. $\mathrm{H}_{2}$-temperature programmed reduction (TPR) profiles for $\mathrm{Au}-\mathrm{Cu}$ catalysts supported on (a) single and (b) dual metal oxides.

On the other hand, the displacement of the reduction peaks to lower temperatures has been associated with changes in metal-support interactions [48]. $\mathrm{CeO}_{2}$ shows an exceptional ability to facilitate the reduction of $\mathrm{Cu}$ and the formation of (mostly) $\beta$ species. This effect has been previously studied [9,52], correlating a stronger $\mathrm{CuO}-\mathrm{CeO}_{2}$ interaction with high activity during CO-PROX. However, the increase in the contribution of $\gamma$-species and a slight shift of reduction peaks to higher temperatures could indicate a variation of the $\mathrm{CuO}-\mathrm{CeO}_{2}$ interaction in the $\mathrm{Au}-\mathrm{Cu}$ catalysts supported in dual oxides. Thus, a change in the redox properties of the support caused by the presence of a second metal oxide could explain why the $\mathrm{Au}-\mathrm{Cu}$ catalysts supported on dual oxides (i.e., $\mathrm{AuCu} / \mathrm{CeO}{ }_{2}-\mathrm{SiO}_{2}$, $\mathrm{AuCu} / \mathrm{CeO}_{2}-\mathrm{ZrO}_{2}$, and $\mathrm{AuCu} / \mathrm{CeO}_{2}-\mathrm{Al}_{2} \mathrm{O}_{3}$ ) showed less activity compared to $\mathrm{AuCu} / \mathrm{CeO}_{2}$ (Figure 2). However, an exceedingly strong $\mathrm{CuO}$-support interaction could also mitigate the formation of selective $\mathrm{Au}-\mathrm{Cu}$ alloys [31]. In fact, $\mathrm{AuCu} / \mathrm{ZrO} \mathrm{O}_{2}$ and $\mathrm{AuCu} / \mathrm{CeO}_{2}-\mathrm{ZrO}_{2}$ show a significant contribution of $\alpha$ species, which could be related to the high $\mathrm{H}_{2}$ loss observed in these catalysts (Figure $3 c, d$ ). On the contrary, the combination of inert metal oxides such as $\mathrm{Al}_{2} \mathrm{O}_{3}$ with $\mathrm{CeO}_{2}$ could facilitate the migration 
of $\mathrm{CuO}$ towards $\mathrm{Au}$ particles [31], leading to lower $\mathrm{H}_{2}$ loss compared to single $\mathrm{CeO}_{2}$ support. Then, the change in redox properties of $\mathrm{CeO}_{2}$ by the presence of inert metal oxides (e.g., $\mathrm{SiO}_{2}$ ) could lead to less active but more selective materials during $\mathrm{CO}$ removal.

Table 1 shows the $\mathrm{H} / \mathrm{M}$ index, which has been associated with apparent active metal dispersion [53]. The $\mathrm{H} / \mathrm{M}$ index in $\mathrm{AuCu} / \mathrm{Fe}_{2} \mathrm{O}_{3}$ and $\mathrm{AuCu} / \mathrm{La}_{2} \mathrm{O}_{3}$ is particularly low, indicating that these catalysts are not as effective for dispersing active metals [53]. In the other catalysts, the $\mathrm{H} / \mathrm{M}$ index was close to or larger than 1.0 (i.e., complete reduction of $\mathrm{Au}$ and $\mathrm{Cu}$ ), which could be associated with a higher dispersion of $\mathrm{Au}$ and $\mathrm{Cu}$ on the catalytic surface. However, a high $\mathrm{H} / \mathrm{M}$ value could also indicate an additional effect of superficial reduction of the supports by the interaction between metal oxides and active metals [54]. Au-Cu catalysts supported on dual metal oxides showed higher H/M index compared to their respective single supports, which could be associated with a favoring in the reduction of both active metals and support due to the interaction between metal oxides. If so, then the redox properties of $\mathrm{Au}-\mathrm{Cu}$ catalysts supported on dual oxides would depend on several interactions: (i) active metal-active metal; (ii) active metal-support, and (iii) oxide I-oxide II. The variation of these interactions influences catalytic performance during $\mathrm{CO}$ removal.

\subsubsection{BET Area}

The surface area of the catalysts is key to the availability of the active sites and catalytic performance [55]. The BET area (Table 1) of the catalysts supported on basic oxides (i.e., $\mathrm{CeO}_{2}, \mathrm{ZrO}_{2}$ and $\mathrm{La}_{2} \mathrm{O}_{3}$ [56]) is larger than their respective bare supports (Table A1 in Appendix B), which has been previously associated with the formation of high disperse $\beta$ species $[20,57]$. On the other hand, $\mathrm{AuCu} / \mathrm{Fe}_{2} \mathrm{O}_{3}$ and $\mathrm{AuCu} / \mathrm{La}_{2} \mathrm{O}_{3}$ show low surface areas, which match to the low capacity of these metal oxides to disperse active metals (low H/M index, Table 1). The synthesis method of the catalysts could influence the surface area of the support, overcoming some drawbacks of metal oxides such as $\mathrm{Fe}_{2} \mathrm{O}_{3}$ by using alternative synthesis methods [32,58]. In contrast, the higher surface area of $\mathrm{AuCu} / \mathrm{CeO}_{2}-\mathrm{Al}_{2} \mathrm{O}_{3}$ and $\mathrm{AuCu} / \mathrm{CeO}_{2}-\mathrm{SiO}_{2}$ could favor the dispersion of $\mathrm{Au}$ and $\mathrm{Cu}$, which is reflected by a larger $\mathrm{H} / \mathrm{M}$ index (Table 1).

Although an increase in the surface area could contribute to improving the catalytic activity [55], the trend for surface area of the catalysts does not match their activity (Figure 2), indicating that the supports have other features that could be more relevant during the $\mathrm{CO}$ removal. Figure 7 shows the conversion rate of $\mathrm{CO}$ normalized by the surface area of catalysts. $\mathrm{AuCu} / \mathrm{La}_{2} \mathrm{O}_{3}$ has a high normalized activity, possibly because the basic supports promote the formation of $\mathrm{Au}$ nanoparticles [33] and formation of $\beta$ species [20,57], which are active in the CO conversion. In fact, basic oxides, such as $\mathrm{CeO}_{2}$ and $\mathrm{ZrO}_{2}$, also have higher normalized activity compared to less basic supports, such as $\mathrm{Al}_{2} \mathrm{O}_{3}$ and $\mathrm{SiO}_{2}$. Also, the normalized activity of the $\mathrm{AuCu} / \mathrm{CeO}_{2}-\mathrm{ZrO}_{2}$ catalyst increases compared to their respective single supports. Recently, it was reported that the replacement of $\mathrm{Zr}^{4+}$ ions in the lattice of the $\mathrm{CaO}-\mathrm{CeO}_{2}$ system leads to the formation of highly basic sites [59]. Then, we speculate that the high interaction in $\mathrm{CeO}_{2}-\mathrm{ZrO}_{2}$ observed by TPR could lead to the formation of sites with greater basicity. However, the low surface area of basic supports is a well-known limitation that affects their activity [6]. So, because of the possible role of basic sites in CO removal, the design of catalysts for CO removal should include a support with both a high surface area and elevated basicity. Modifications in the morphology of metal oxides have been proposed as a successful strategy to achieve this objective in other catalytic processes [60]. Then, preparation of $\mathrm{Au}-\mathrm{Cu}$ catalysts supported on single and dual metal oxides can be optimized to improve their catalytic properties during $\mathrm{CO}$ removal. 

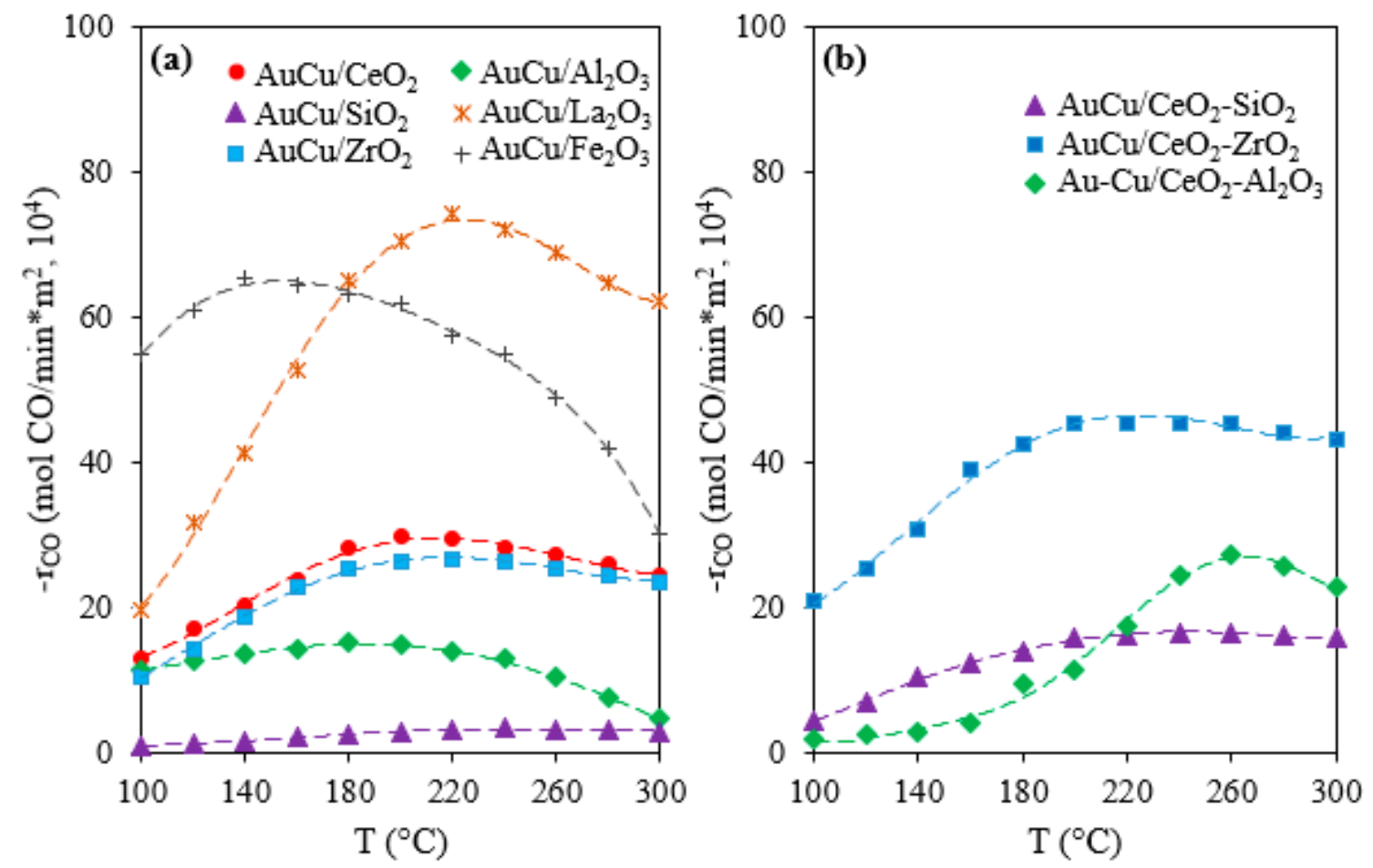

Figure 7. CO conversion rate normalized by the surface area of the $\mathrm{Au}-\mathrm{Cu}$ catalysts supported in (a) single and (b) dual metal oxides.

\subsubsection{OSC Measurements}

The OSC of the support plays a central role in the oxidation of CO adsorbed on active sites [27]. Table 1 shows the OSC of $\mathrm{Au}-\mathrm{Cu}$ catalysts supported on single and dual metal oxides. In general, the OSC of supported $\mathrm{Au}-\mathrm{Cu}$ catalysts is higher than that of the bare supports (Table A1 in Appendix B), indicating that the presence of $\mathrm{Au}$ and $\mathrm{Cu}$ favors greater oxygen mobility in the catalyst. Also, the presence of $\alpha$ and $\beta$ species has been associated with the formation of oxygen vacancies on the catalytic surface [52]. Catalysts that have a higher OSC at $300{ }^{\circ} \mathrm{C}$ (i.e., $\mathrm{AuCu} / \mathrm{CeO}_{2}-\mathrm{ZrO}_{2}, \mathrm{AuCu} / \mathrm{CeO}_{2}$, $\mathrm{AuCu} / \mathrm{CeO}_{2}-\mathrm{SiO}_{2}$, and $\mathrm{AuCu} / \mathrm{ZrO}_{2}$ ) were the most active (Figure 2), but also those that showed the highest consumption of $\mathrm{H}_{2}$ (Figure 3). However, the OSC depends strongly on the temperature: at 100 ${ }^{\circ} \mathrm{C}$, all catalysts except $\mathrm{AuCu} / \mathrm{Al}_{2} \mathrm{O}_{3}$ showed an OSC up to $60 \%$ lower compared to $300{ }^{\circ} \mathrm{C}$, which could be related to the lower activity of catalysts at low temperatures (Figure 2).

Likewise, the $\mathrm{CO}_{2}$ formation depends on the availability of surface oxygen [15]. The first $\mathrm{CO}$ pulse (OSC) in $\mathrm{AuCu} / \mathrm{CeO}_{2}$ only corresponds to $39 \%$ of its oxygen storage complete capacity (OSCC), indicating that oxygen adsorbed on $\mathrm{CeO}_{2}$ may not be easily released. The possible deficiency of $\mathrm{CeO}_{2}$ to release the oxygen absorbed on its surface could limit the oxidation of carbon intermediates, which could, in turn, be related to the atypical trend observed in Figure $4 \mathrm{~b}$. The OSC in supports with larger surface area (i.e., $\mathrm{AuCu} / \mathrm{SiO}_{2}, \mathrm{AuCu} / \mathrm{Al}_{2} \mathrm{O}_{3}, \mathrm{AuCu} / \mathrm{CeO}_{2}-\mathrm{SiO}_{2}$, and $\mathrm{AuCu} / \mathrm{CeO}_{2}-\mathrm{Al}_{2} \mathrm{O}_{3}$ ), on the other hand, corresponds to more than $50 \%$ of their OSCC. A higher availability of surface oxygen (> OSC/OSCC) could be associated with the strong effect of $\mathrm{CO}_{2}$ methanation on the $\mathrm{CO}$ removal for $\mathrm{AuCu} / \mathrm{CeO}_{2}-\mathrm{SiO}_{2}$ and $\mathrm{AuCu} / \mathrm{CeO}_{2}-\mathrm{Al}_{2} \mathrm{O}_{3}$, as previously discussed. If so, then the beneficial effect of methanation during the CO-PROX proposed by [16] could be enhanced in catalysts that combine a high OSC and readiness to release their adsorbed oxygen (i.e., high OSC/OSCC ratio), which would require a high surface area. 
On the other hand, the OSCC of the catalysts used decreases with respect to the fresh, activated ones (AC samples), reaching up to $73 \%$ reduction with $\mathrm{AuCu} / \mathrm{La}_{2} \mathrm{O}_{3}$. This reduction could be associated with progressive oxidation of the catalyst surface by the presence of oxidants in the gas stream and deposits on the catalytic surface [20], conducive of a progressive deactivation. To clarify this, a TGA study was conducted.

\subsubsection{TGA}

Table 3 shows the weight loss of $\mathrm{Au}-\mathrm{Cu}$ catalysts supported on single and dual metal oxides. Most AC samples show a weight loss of less than $1 \%$ that could correspond to a remnant of the precursors of the active metals. However, $\mathrm{AuCu} / \mathrm{Fe}_{2} \mathrm{O}_{3}$ and $\mathrm{AuCu} / \mathrm{CeO}_{2}-\mathrm{SiO}_{2}$ show an increase in weight that can be associated with an oxygen adsorption; specifically, the $\mathrm{CeO}_{2}-\mathrm{SiO}_{2}$ system can form a $\mathrm{Ce}_{9.33}\left(\mathrm{SiO}_{4}\right) \cdot 6 \mathrm{O}_{2}$ phase that is susceptible to consume oxygen above $600{ }^{\circ} \mathrm{C}$ [6]. The used catalysts have a higher weight loss than the fresh, activated ones (AC samples), indicating the presence of compounds deposited on the catalytic surface during the reaction. To determine the nature of the deposits, the TGA results were analyzed by weight loss in terms of rate of carbon equivalent formed in each temperature interval (Table 3). In the first interval $\left(40-250{ }^{\circ} \mathrm{C}\right)$, light compounds, such as water, and adsorbed $\mathrm{OH}^{-}$and gases are released [28]; in this interval, $\mathrm{AuCu} / \mathrm{SiO}_{2}$ and $\mathrm{AuCu} / \mathrm{Al}_{2} \mathrm{O}_{3}$ showed the highest weight loss, which could be related to their high surface area, which favors moisture adsorption. In the second interval $\left(250-600{ }^{\circ} \mathrm{C}\right)$, light hydrocarbons are oxidized [26]; $\mathrm{AuCu} / \mathrm{La}_{2} \mathrm{O}_{3}$ and $\mathrm{AuCu} / \mathrm{Fe}_{2} \mathrm{O}_{3}$ had the highest rate of carbon formation in this interval, which would explain the strong decrease in the OSCC and surface area, respectively, observed in these samples (Table 1). In the last interval $\left(600-1000^{\circ} \mathrm{C}\right)$, heavy hydrocarbons are oxidized, which are the type of deposits that could favor a faster deactivation of the catalyst [56]; in this zone, $\mathrm{AuCu} / \mathrm{CeO}_{2}$ showed a higher rate of carbon formation. Thus, rapid deactivation observed in $\mathrm{AuCu} / \mathrm{CeO}_{2}$ (Figure 5) could be associated with the decrease in surface area $(17 \%$, Table 1$)$ and OSCC $(59 \%$, Table 1$)$ promoted by the accumulation of deposits on the catalytic surface (Table 3). The formation of stable deposits could be associated with the formation of intermediates during the CO removal [28]; therefore, in situ DRIFTS was carried out to identify how the interaction between $\mathrm{CO}$ and support affects the performance of the supported $\mathrm{Au}-\mathrm{Cu}$ catalysts.

Table 3. Weight loss of $\mathrm{Au}-\mathrm{Cu}$ catalysts supported on single and dual supports evaluated in $\mathrm{CO}$ removal from an actual syngas.

\begin{tabular}{|c|c|c|c|c|c|}
\hline \multirow[t]{2}{*}{ Catalyst } & \multicolumn{2}{|c|}{ Total Weight Loss (\%) } & \multicolumn{3}{|c|}{$\begin{array}{l}\text { Weight Loss of Spent Catalyst Samples by } \\
\left.\text { Temperature Intervals (mg of C/g } / \mathrm{gat}^{*} \mathrm{~h}\right)\end{array}$} \\
\hline & $\mathrm{AC}$ & Spent & $40-250{ }^{\circ} \mathrm{C}$ & $250-600{ }^{\circ} \mathrm{C}$ & $600-1000{ }^{\circ} \mathrm{C}$ \\
\hline \multirow[t]{2}{*}{$\mathrm{AuCu} / \mathrm{CeO}_{2}$} & 0.7 & $3.8(\mathrm{U})$ & $17.1(\mathrm{U})$ & $6.8(\mathrm{U})$ & $11.8(\mathrm{U})$ \\
\hline & & $5.6(S)$ & $14.5(\mathrm{~S})$ & $15.1(\mathrm{U})$ & $18.1(\mathrm{U})$ \\
\hline $\mathrm{AuCu} / \mathrm{SiO}_{2}$ & 0.3 & $3.7(\mathrm{U})$ & 35.5 (U) & $3.4(\mathrm{U})$ & $3.9(\mathrm{U})$ \\
\hline $\mathrm{AuCu} / \mathrm{ZrO}_{2}$ & 0.9 & $1.6(\mathrm{U})$ & $9.2(\mathrm{U})$ & $2.1(\mathrm{U})$ & $4.7(\mathrm{U})$ \\
\hline $\mathrm{AuCu} / \mathrm{Al}_{2} \mathrm{O}_{3}$ & 0.5 & $3.7(\mathrm{U})$ & $28.9(\mathrm{U})$ & $2.1(\mathrm{U})$ & $9.4(\mathrm{U})$ \\
\hline $\mathrm{AuCu} / \mathrm{La}_{2} \mathrm{O}_{3}$ & 0.6 & $2.1(\mathrm{U})$ & $9.2(\mathrm{U})$ & $7.5(\mathrm{U})$ & $2.4(\mathrm{U})$ \\
\hline $\mathrm{AuCu} / \mathrm{Fe}_{2} \mathrm{O}_{3}$ & -0.3 & $2.5(\mathrm{U})$ & $18.4(\mathrm{U})$ & $8.9(\mathrm{U})$ & NR \\
\hline \multirow[t]{2}{*}{$\mathrm{AuCu} / \mathrm{CeO}_{2}-\mathrm{SiO}_{2}$} & -0.9 & $0.3(\mathrm{U})$ & $3.9(\mathrm{U})$ & $4.8(\mathrm{U})$ & NR \\
\hline & & $1.3(S)$ & $15.8(S)$ & $4.1(\mathrm{U})$ & NR \\
\hline $\mathrm{AuCu} / \mathrm{CeO}_{2}-\mathrm{ZrO}_{2}$ & 0.5 & $1.7(\mathrm{U})$ & $9.2(\mathrm{U})$ & $6.2(\mathrm{U})$ & $0.8(\mathrm{U})$ \\
\hline $\mathrm{AuCu} / \mathrm{CeO}_{2}-\mathrm{Al}_{2} \mathrm{O}_{3}$ & 0.6 & $2.6(\mathrm{U})$ & $17.1(\mathrm{U})$ & $2.7(\mathrm{U})$ & $7.1(\mathrm{U})$ \\
\hline
\end{tabular}

Note: $\mathrm{AC}=$ activated catalyst, which were reduced with $\mathrm{H}_{2}$ and stabilized in air before activity tests; $\mathrm{U}=$ sample used to obtain light-off curves; $\mathrm{S}=$ sample evaluated in the stability test; NR = Not reported. 


\subsubsection{In Situ DRIFTS}

Figure 8 shows the DRIFTS spectra of $\mathrm{CO}$ adsorption on bare supports and supported $\mathrm{Au}-\mathrm{Cu}$ catalysts. $\mathrm{CeO}_{2}$ and $\mathrm{ZrO}_{2}$ show higher intensity in the area associated with hydroxyl groups $\left(\sim 3500 \mathrm{~cm}^{-1}\right)$ that contributes to the CO conversion [36], which would explain their high activity among single metal oxides (Figure 2). Although the $\mathrm{CO}$ pulses were free of $\mathrm{H}_{2}$ or water, hydroxyl groups may be formed from the interaction of $\mathrm{H}_{2}$ with the surface of the support [61], which could occur during the $\mathrm{H}_{2}$ reduction that was performed on the AC samples. In fact, Zhou et al. [62] studied the CO adsorption on bare $\mathrm{ZrO}_{2}$ by DRIFTS and Fourier Transform Infrared Spectroscopy (FTIR), identifying up to three families of hydroxyl groups in the zone from 3675 to $3772 \mathrm{~cm}^{-1}$, which are activated by the adsorption of $\mathrm{CO}$, even at room temperature, and have an active role in the formation of surface intermediates. $\mathrm{CeO}_{2}$ favors the formation of hydroxyl groups even with the first pulse of $\mathrm{CO}$, which could be decisive in ensuring a syngas with a lower $\mathrm{CO}$ concentration. In the $\mathrm{C}-\mathrm{O}^{*}$ zone (1200 to $1700 \mathrm{~cm}^{-1}$ [63]), the formation of bidentate carbonates $\left(1600 \mathrm{~cm}^{-1}\right)$ and formates $\left(1300\right.$ and $\left.1500 \mathrm{~cm}^{-1}\right)$ are observed, which are also intermediates in the CO conversion $[20,51,63]$. The formation of hydroxyl groups and $\mathrm{C}-\mathrm{O}^{*}$ species were lower than dual supports when compared to $\mathrm{CeO}_{2}$; specifically, $\mathrm{CeO}_{2}-\mathrm{Al}_{2} \mathrm{O}_{3}$ shows a significant reduction in the formation of $\mathrm{C}-\mathrm{O}^{*}$ intermediates, which would correspond to its lower activity among the dual supports (Figure 2).

The inclusion of $\mathrm{Au}-\mathrm{Cu}$ in the single oxides (Figure 8c) favors the presence of hydroxyls and the formation of $\mathrm{C}-\mathrm{O}^{*}$ intermediates, possibly due to the ability of $\mathrm{Au}$ to form $\mathrm{Au}-\mathrm{CO}$ and $\mathrm{Au}-\mathrm{OOH}$ species [36]. In fact, most catalysts show an increase in CO adsorbed $\left(2100 \mathrm{~cm}^{-1}\right)$, which is associated with $\mathrm{CO}-\mathrm{Au}^{0}$ species [64], indicating that $\mathrm{Au}$ could be present mostly as $\mathrm{Au}^{0}$ on the catalytic surface, as previously reported for systems such as $\mathrm{Au} / \mathrm{CeO}_{2}$ [20] and $\mathrm{Au} / \mathrm{La}_{2} \mathrm{O}_{3} / \mathrm{Al}_{2} \mathrm{O}_{3}$ [33], evaluated by XPS. However, in $\mathrm{AuCu} / \mathrm{CeO}_{2}-\mathrm{SiO}_{2}$ and $\mathrm{AuCu} / \mathrm{CeO}_{2}-\mathrm{ZrO}_{2}$, a weak peak of $\mathrm{CO}$ adsorption between 2075 and $2050 \mathrm{~cm}^{-1}$ is also observed, which has been associated with the formation of $\mathrm{CO}-\mathrm{Au}^{\mathrm{\delta}}$ species [65]. In the case of $\mathrm{AuCu} / \mathrm{CeO}_{2}-\mathrm{ZrO}_{2}$, the formation of these species only occurs after several $\mathrm{CO}$ pulses. The presence of $\mathrm{Au}^{\delta-}$ has been related to a stronger support-metal interaction, which could be ascribed to the high stability of $\mathrm{AuCu} / \mathrm{CeO}_{2}-\mathrm{SiO}_{2}$ (Figure 5).

The formation of $\mathrm{C}-\mathrm{O}^{*}$ intermediates may occur on different active sites, including $\mathrm{Au}^{0}, \mathrm{Au}^{\delta}$, and $\mathrm{CuO}$, but the formation of carbonate species at approximately $1470 \mathrm{~cm}^{-1}$ occurs preferably on $\mathrm{Cu}^{+}$ species [66], which are very active in CO-PROX [67]. The peak associated with $\mathrm{Cu}^{+}$is well defined in $\mathrm{AuCu} / \mathrm{CeO}_{2}$. Furthermore, the formation of active $\mathrm{Cu}^{+}$species due to the high affinity in $\mathrm{CuO}-\mathrm{CeO}_{2}$ has been extensively studied by XPS and DRIFTS $[25,68]$. Thus, a smaller amount of $\mathrm{Cu}^{+}$species on the other catalysts could explain their inability to ensure CO concentrations below $100 \mathrm{ppm}$ (Table 1). Besides, the peaks associated with formate species, which are related to $\mathrm{CH}_{4}$ formation, are better defined on $\mathrm{CeO}_{2}$. It is accepted that $\mathrm{CH}_{4}$ formation is promoted on several oxides (e.g., $\mathrm{Al}_{2} \mathrm{O}_{3}, \mathrm{ZrO}_{2}$, $\mathrm{Y}_{2} \mathrm{O}_{3}, \mathrm{MgO}$, and $\mathrm{CeO}_{2}$ [69]), but the special ability to adsorb and activate carbon species makes $\mathrm{CeO}_{2}$ an adequate support in $\mathrm{CO}_{2}$ methanation and CO-SMET [70]. Nevertheless, during the $\mathrm{CO}$ removal the Boudouard reaction and the $\mathrm{CH}_{4}$ decomposition could contribute to the production of carbon deposits [26], favoring the catalyst deactivation. Then, the ability of $\mathrm{CeO}_{2}$ to form $\mathrm{C}-\mathrm{O}^{*}$ intermediates (Figure 8 ) assisted by $\mathrm{Cu}^{+}$species and its lower capacity to release the surface oxygen (low OSC/OSCC) could contribute to the generation of stable carbon deposits, as was observed by TGA, leading to its rapid deactivation (Figure 5). Besides, the deficiency of $\mathrm{AuCu} / \mathrm{CeO}_{2}$ to mitigate carbon deposition due to the excessive formation of $\mathrm{C}-\mathrm{O}^{*}$ intermediates could be also related to the atypical behavior of $\mathrm{CH}_{4}$ formation (Figure $4 \mathrm{~b}$ ). However, the less active materials show low formation of intermediates (e.g., $\mathrm{AuCu} / \mathrm{La}_{2} \mathrm{O}_{3}, \mathrm{AuCu} / \mathrm{Fe}_{2} \mathrm{O}_{3}$, and $\mathrm{AuCu} / \mathrm{SiO}_{2}$ ). Thus, the selection of the support for the $\mathrm{CO}$ removal from a syngas must consider the balance between activity and stability. 

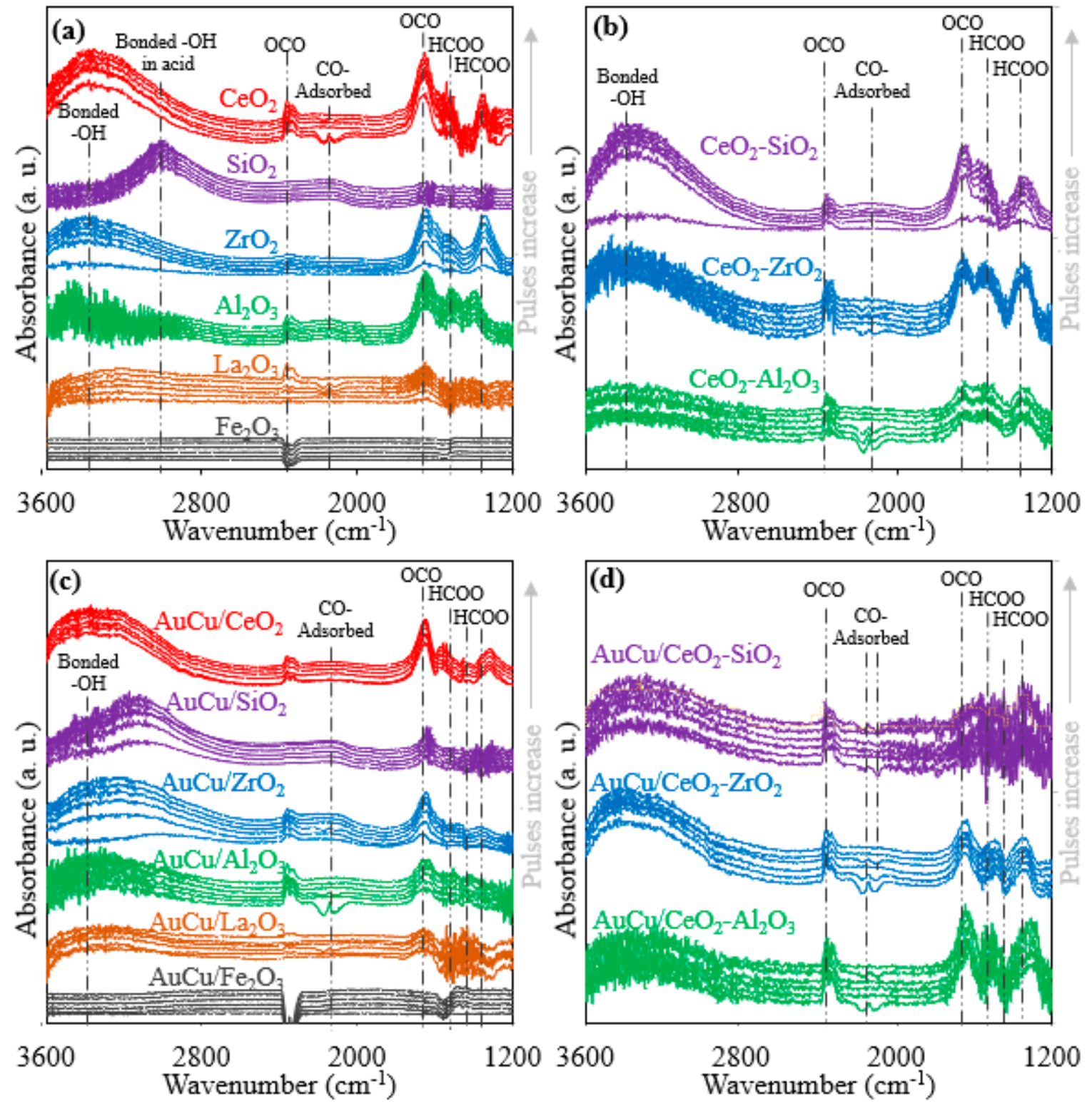

Figure 8. In situ diffuse reflectance infrared Fourier transform spectroscopy (DRIFTS) of CO adsorption of $(\mathbf{a}, \mathbf{b})$ bare supports and $(\mathbf{c}, \mathbf{d})$ supported $\mathrm{Au}-\mathrm{Cu}$ catalysts.

The results of DRIFTS support the notion that the use of dual metal oxides favors less active but more stable catalysts. Therefore, in this study, $\mathrm{CeO}_{2}$ is presented as the most promising support for developing a compact system to carry out the $\mathrm{CO}$ removal from an actual syngas. However, the selectivity and stability of $\mathrm{CeO}_{2}$ require improvements. Furthermore, it was shown that the use of dual supports, specifically $\mathrm{CeO}_{2}-\mathrm{SiO}_{2}$ and $\mathrm{CeO}_{2}-\mathrm{ZrO}_{2}$, could be a promising strategy to overcome the deficiencies presented by $\mathrm{CeO}_{2}$.

\section{Materials and Methods}

\subsection{Support Selection}

The supports evaluated in this work were selected according to a literature review, and are summarized in Figure 1. Scientific articles published between 2012 and 2019 that included at least one of the following reactions were reviewed: CO-PROX, WGSR, and CO-SMET. The detailed list of reviewed articles can be consulted in Table A2 (see Appendix B). 


\subsection{Catalyst Synthesis}

The single supports of $\mathrm{CeO}_{2}, \mathrm{ZrO}_{2}$, and $\mathrm{Fe}_{2} \mathrm{O}_{3}$ were obtained by calcination at $500{ }^{\circ} \mathrm{C}$ for $2 \mathrm{~h}$ of $\mathrm{Ce}\left(\mathrm{NO}_{3}\right)_{3} \cdot 6 \mathrm{H}_{2} \mathrm{O}$ (CAS: 10294-41-4, Sigma Aldrich, Saint Louis, $\left.\mathrm{MO}, \mathrm{USA}\right), \mathrm{ZrO}\left(\mathrm{NO}_{3}\right)_{2} \cdot \mathrm{xH}_{2} \mathrm{O}(\mathrm{CAS}$ : 14985-18-3, Sigma Aldrich, Saint Louis, MO, USA), and $\mathrm{Fe}\left(\mathrm{NO}_{3}\right)_{3} \cdot 9 \mathrm{H}_{2} \mathrm{O}$ (CAS: 7782-61-8, Merck, Darmstadt, HE, Germany), respectively. Also, commercial oxides of $\mathrm{La}_{2} \mathrm{O}_{3}$ (CAS: 1312-81-8, Sigma Aldrich, Saint Louis, MO, USA), $\mathrm{Al}_{2} \mathrm{O}_{3}$ (CAS: 1344-28-1, Sigma Aldrich, Saint Louis, MO, USA), and $\mathrm{SiO}_{2}$ (CAS: 60676-86-0, Merck, Darmstadt, HE, Germany) were used, which were also calcined at $500{ }^{\circ} \mathrm{C}$ in a muffle for $2 \mathrm{~h}$.

Dual supports of $\mathrm{CeO}_{2}-\mathrm{ZrO}_{2}, \mathrm{CeO}_{2}-\mathrm{Al}_{2} \mathrm{O}_{3}$, and $\mathrm{CeO}_{2}-\mathrm{SiO}_{2}$ were obtained from aqueous solutions of Ce Ce( $\left(\mathrm{NO}_{3}\right)_{3} \cdot 6 \mathrm{H}_{2} \mathrm{O}$ (CAS: 10294-41-4, Sigma Aldrich, Saint Louis, MO, USA) with $\mathrm{ZrO}\left(\mathrm{NO}_{3}\right)_{2} \cdot \mathrm{H}_{2} \mathrm{O}$ (CAS: 14985-18-3, Sigma Aldrich, Saint Louis, MO, USA), $\mathrm{Al}_{2} \mathrm{O}_{3}$ (CAS: 1344-28-1, Sigma Aldrich, Saint Louis, MO, USA), and $\mathrm{SiO}_{2}$ (CAS: 60676-86-0, Merck, Darmstadt, HE, Germany), respectively, ensuring a molar ratio of $\mathrm{Ce} / \mathrm{M}=1(\mathrm{M}=\mathrm{Si}, \mathrm{Zr}$ and $\mathrm{Al})$. Each solution was dried at $80^{\circ} \mathrm{C}$ for $24 \mathrm{~h}$ and calcined at $500{ }^{\circ} \mathrm{C}$ in a muffle for $4 \mathrm{~h}$. All supports (i.e., single and dual metal oxides) were screened with a 140-mesh sieve.

Bimetallic $\mathrm{Au}-\mathrm{Cu}$ catalysts supported on each single and dual metal oxide were prepared according to the procedure described in [20], ensuring active metal loads of $\mathrm{Au}(1 \mathrm{wt} \%)$ and $\mathrm{Cu}$ $(1 \mathrm{wt} \%)$. Au was first impregnated on each support by the precipitation-deposition method at $\mathrm{pH} 6$ and $80^{\circ} \mathrm{C}$, using a solution of $\mathrm{HAuCl}_{4} \cdot 3 \mathrm{H}_{2} \mathrm{O}$ (CAS: 16961-25-4 Sigma Aldrich, MO, USA). The filtered solid was dried at $80^{\circ} \mathrm{C}$ for $24 \mathrm{~h}$. Subsequently, $\mathrm{Cu}$ was included in the Au catalysts by the incipient wetness impregnation method, using a solution of $\mathrm{Cu}\left(\mathrm{NO}_{3}\right)_{2} \cdot 3 \mathrm{H}_{2} \mathrm{O}$ (CAS: 10031-43-3, Sigma Aldrich, Saint Louis, MO, USA). The catalyst obtained was dried at $80^{\circ} \mathrm{C}$ for $24 \mathrm{~h}$, calcined at $500{ }^{\circ} \mathrm{C}$ in a muffle for $2 \mathrm{~h}$, and screened with a 140-mesh sieve.

The $\mathrm{RhPt} / \mathrm{CeO}_{2}-\mathrm{SiO}_{2}$ catalyst for ESR was prepared according to the methodology described in [6]. Briefly, $\mathrm{CeO}_{2}-\mathrm{SiO}_{2}$ support was obtained from $\mathrm{Ce}\left(\mathrm{NO}_{3}\right)_{3} \cdot 6 \mathrm{H}_{2} \mathrm{O}$ (CAS: 10294-41-4, Sigma Aldrich, Saint Louis, MO, USA) and $\mathrm{SiO}_{2}$ (CAS: 60676-86-0, Merck, Darmstadt, HE, Germany) solutions, ensuring a molar ratio of $\mathrm{Ce} / \mathrm{Si}=2$. $\mathrm{Rh}$ and $\mathrm{Pt}$ were deposited on the $\mathrm{CeO}_{2}-\mathrm{SiO}_{2}$ support by the incipient wetness co-impregnation method, using $\mathrm{RhCl}_{3} \cdot \mathrm{H}_{2} \mathrm{O}$ (CAS: 20765-98-4, Sigma Aldrich, Saint Louis, MO, USA) and $\mathrm{H}_{2} \mathrm{PtCl}_{6} \cdot 6 \mathrm{H}_{2} \mathrm{O}$ (CAS: 10025-65-7, Sigma Aldrich, Saint Louis, MO, USA) solutions. The catalyst obtained was dried at $80^{\circ} \mathrm{C}$ for $24 \mathrm{~h}$, calcined at $700{ }^{\circ} \mathrm{C}$ for $2 \mathrm{~h}$, and screened with a 140-mesh sieve.

\subsection{Obtaining Syngas}

The syngas was obtained from ESR with a $\mathrm{RhPt} / \mathrm{CeO}_{2}-\mathrm{SiO}_{2}$ catalyst at $700{ }^{\circ} \mathrm{C}$ in the first reactor (ESR reactor). The plug flow conditions in the ESR reactor were maintained ensuring $L / D p>50$ ratios (i.e., catalytic bed height $(L)$ and catalyst particle size $(D p)$ ) and $D / D p>60$ (i.e., diameter internal to the reactor $(D)$ ), as recommended in [71]. The catalyst bed consisted of $0.050 \mathrm{~g}$ of $\mathrm{RhPt} / \mathrm{CeO}_{2-} \mathrm{SiO}_{2}$ and $0.250 \mathrm{~g}$ of inert quartz. The reactor feed consisted of $0.3 \mathrm{~L} / \mathrm{min}$ of a mixture of ethanol $(1.8 \mathrm{~mol} \%)$, water $(5.4 \mathrm{~mol} \%)$, and Ar as carrier gas. The space velocity (SV) was set at $6.4 \pm 0.2 \mathrm{~L} / \mathrm{gcat}^{*} \mathrm{~min}$. The syngas obtained in the ESR reactor, containing $\mathrm{H}_{2}(8.4 \mathrm{~mol} \%), \mathrm{CO}(2.2 \mathrm{~mol} \%), \mathrm{H}_{2} \mathrm{O}(1.6 \mathrm{~mol} \%), \mathrm{CO}_{2}(0.6 \mathrm{~mol} \%)$, $\mathrm{CH}_{4}(0.3 \mathrm{~mol} \%)$, and $\mathrm{Ar}(86.9 \mathrm{~mol} \%)$, remained stable, with a variation $<6.8 \%$.

\subsection{Catalytic Test}

The supports and $\mathrm{Au}-\mathrm{Cu}$ catalysts for the $\mathrm{CO}$ removal from the syngas were evaluated in a second reactor (cleanup reactor) between 100 and $300{ }^{\circ} \mathrm{C}$. For this, the ESR reactor outlet was mixed with dry air, ensuring an excess oxygen factor $(\lambda)$ of $1.8 \pm 0.05$ [20], and connected to the cleanup reactor inlet. The plug flow conditions in the cleanup reactor were maintained as previously described for the ESR reactor. The catalyst bed consisted of $0.050 \mathrm{~g}$ of catalyst (i.e., supports or $\mathrm{Au}-\mathrm{Cu}$ catalysts) and $0.250 \mathrm{~g}$ of inert quartz. The SV in the cleanup reactor was set at $6.5 \pm 0.3 \mathrm{~L} / \mathrm{g}_{\mathrm{cat}}{ }^{*} \mathrm{~min}$. Before the reaction, the supports and $\mathrm{Au}-\mathrm{Cu}$ catalysts were pretreated in situ at $300{ }^{\circ} \mathrm{C}$ with streams of $8 \% \mathrm{H}_{2} / \mathrm{Ar}$ for $1 \mathrm{~h}$, 
followed by Ar for $0.5 \mathrm{~h}$, and finally $10 \%$ air/Ar for $0.5 \mathrm{~h}$. These samples were labeled as "activated catalyst" (AC). Also, the samples used to obtain the light-off curves were labeled " $U$ ", while those used in the stability test were labeled " $\mathrm{S}$ ".

The species at the outlet of each reactor (i.e., ESR reactor and cleanup reactor) were quantified by gas chromatography (GC) in a Clarus 580 (Perkin Elmer, Waltham, MA, USA), equipped with a Carboxen 1010 plot column (30 m, 0.53 mm ID, Restek, Bellefonte, PA, USA) connected to a thermal conductivity detector (TCD). Ar was used as carrier gas and $\mathrm{N}_{2}$ as internal reference. The reaction conditions and GC data processed in Excel can be consulted in detail and downloaded from [72].

The conversion of $\mathrm{CO}\left(x_{\mathrm{CO}}\right)$, the production of the main products $\left(Y_{\mathrm{CO}_{2}}\right.$ and $\left.Y_{\mathrm{CH}_{4}}\right)$, and the $\mathrm{H}_{2}$ obtained $\left(Y_{\mathrm{H}_{2}}\right)$ from the integrated system were obtained considering the molar flows $\left(F_{i}\right)$ to the output of each reactor (i.e., ESR reactor and cleanup reactor), according to Equations (1) and (3). Production of $\mathrm{CO}, \mathrm{CH}_{4}$, and $\mathrm{H}_{2}$ were normalized with the amount of carbon entering the system $\left(F_{C}\right.$, inlet to the system $)$, which remained constant at $5.2^{*} 10^{-4} \mathrm{~mol} / \mathrm{min}$ of $\mathrm{C}$.

$$
\begin{gathered}
x_{\mathrm{CO}}=\frac{F_{\mathrm{CO}, \text { ESR-reactor }}-F_{\mathrm{CO}, \text { cleanup-reactor }}}{F_{\mathrm{CO}, \text { ESR-reactor }}} \\
Y_{\mathrm{CH}_{4} ; \mathrm{CO}_{2}}=\frac{F_{\mathrm{CH}_{4} ; \mathrm{CO}_{2} \text {, cleanup-reactor }-F_{\mathrm{CH}_{4} ; \mathrm{CO}_{2}, \text { ESR-reactor }}}}{F_{C, \text { inlet to the system }}} \\
Y_{\mathrm{H}_{2}}=\frac{F_{\mathrm{H}_{2}, \text { cleanup-reactor }}}{F_{C, \text { inlet to the system }}}
\end{gathered}
$$

\subsection{Characterization Tests}

The reducibility of supports and $\mathrm{Au}-\mathrm{Cu}$ catalysts was determined by TPR. The experiments were carried out in a ChemBET Pulsar unit (Quantachrome Instruments, Boynton Beach, FL, USA) equipped with a TCD. Prior to the reduction, $0.07 \pm 0.01 \mathrm{~g}$ of AC samples was pretreated with $\mathrm{N}_{2}(0.02 \mathrm{~L} / \mathrm{min})$ at $120^{\circ} \mathrm{C}$ for $1 \mathrm{~h}$ and then cooled to room temperature. Subsequently, $5 \% \mathrm{H}_{2} / \mathrm{N}_{2}$ was passed, and the temperature was increased to $700{ }^{\circ} \mathrm{C}\left(5^{\circ} \mathrm{C} / \mathrm{min}\right)$. The $\mathrm{H}_{2}$ uptake was calculated by integrating the peaks associated with the reduction of active metals (i.e., $\mathrm{Au}$ and $\mathrm{Cu}$ ). The apparent active metal dispersion ( $\mathrm{H} / \mathrm{M}$ ratio) was also determined [53], assuming that the adsorption stoichiometry is one hydrogen atom for one active metal atom $(\mathrm{Au}+\mathrm{Cu})$.

The surface area of the samples was determined by standard physisorption of $\mathrm{N}_{2}$ in a ChemBET Pulsar unit (Quantachrome Instruments, Boynton Beach, FL, USA). For this, $0.06 \pm 0.01 \mathrm{~g}$ of sample was pretreated with $\mathrm{N}_{2}(0.02 \mathrm{~L} / \mathrm{min})$ at $100{ }^{\circ} \mathrm{C}$ for $1 \mathrm{~h}$ and then cooled to room temperature for $0.5 \mathrm{~h}$. Subsequently, the sample was immersed in a liquid $\mathrm{N}_{2}$ bath. The BET area was measured with a single point, using $30 \% \mathrm{~N}_{2} / \mathrm{He}(0.02 \mathrm{~L} / \mathrm{min})$. The measurements were repeated until deviations lower than $5 \%$ were obtained.

The OSC values of the samples were measured in a ChemBET Pulsar unit (Quantachrome Instruments, Boynton Beach, FL, USA), according to the procedure described in [41]. Briefly, $0.06 \pm 0.01 \mathrm{~g}$ of sample was degassed in $\mathrm{Ar}(0.02 \mathrm{~L} / \mathrm{min})$ at $300{ }^{\circ} \mathrm{C}$ for $1 \mathrm{~h}$. OSC was measured at 300 and $100{ }^{\circ} \mathrm{C}$ with independent samples. For this, 10 pulses of pure $\mathrm{O}_{2}(0.25 \mathrm{~mL})$ were injected to oxidize the sample, followed by a 20 min purge with Ar. Then, pulses of a $5 \% \mathrm{CO} / \mathrm{Ar}$ mixture $(0.25 \mathrm{~mL})$ were injected until a constant signal was obtained. The OSC value was calculated by the CO consumed in the first pulse, and the OSCC value was determined by the total CO consumed. 
The weight loss, associated with the presence of impurities, moisture, and carbon deposition in samples, was measured by TGA. The change in mass was determined using a thermogravimetric analyzer (Mettler Toledo, Columbus, OH, USA). For this, $0.02 \pm 0.01 \mathrm{~g}$ of sample was pretreated with a $\mathrm{N}_{2}(0.1 \mathrm{~L} / \mathrm{min})$ at $100{ }^{\circ} \mathrm{C}$ for $1 \mathrm{~h}$ and then cooled to $40{ }^{\circ} \mathrm{C}$ for $0.5 \mathrm{~h}$. Subsequently, the sample was heated to $1000{ }^{\circ} \mathrm{C}\left(5^{\circ} \mathrm{C} / \mathrm{min}\right)$ in a dry air stream $(0.1 \mathrm{~L} / \mathrm{min})$. Then, the rate of carbon formation was calculated according to Equation (4).

$$
\text { Rate of carbon formation }=\frac{\text { Weight loss in term of } C(m g)}{\text { mass of catalyst }(g) * \text { TGA test time }(h)}
$$

The CO adsorption on supports and catalysts was studied by in situ DRIFTS in a Nicolet iS10 spectrum device (Thermo Scientific, Waltham, MA, USA) equipped with a diffuse reflection attachment DRK-3 Praying Mantis (Harrick Scientific Products, New York, NY, USA). Spectra were taken between 400 and $4000 \mathrm{~cm}^{-1}$, with 64 scans per minute and a resolution of $4 \mathrm{~cm}^{-1}$. The sample holder was sealed with an airtight hood with $\mathrm{ZeSn}$ windows. In addition, the airtight hood was isolated with an Ar stream to avoid interference from the environment. Approximately $0.02 \mathrm{~g}$ of AC samples were degassed in $\operatorname{Ar}(15 \mathrm{~mL} / \mathrm{min})$ at $50{ }^{\circ} \mathrm{C}$ for $30 \mathrm{~min}$. Then, 10 pulses of $30 \mu \mathrm{L}$ of $\mathrm{CO}$, obtained from a certified 5\% CO/Ar mixture, were injected into the cell; between each pulse, $\mathrm{Ar}(15 \mathrm{~mL} / \mathrm{min})$ was passed for $10 \mathrm{~min}$.

Raw and processed Excel data for characterization tests can be downloaded from [72].

\section{Conclusions}

Several single and dual metal oxides were investigated as supports in a catalytic system based on $\mathrm{Au}-\mathrm{Cu}$ for the $\mathrm{CO}$ removal from an actual syngas. The use of a syngas obtained directly from the ESR affects the effectiveness in the $\mathrm{CO}$ removal; specifically, a low $\mathrm{H}_{2} / \mathrm{CO}$ ratio could favor greater $\mathrm{H}_{2}$ loss. $\mathrm{AuCu} / \mathrm{CeO}_{2}$ was identified as the most active catalyst in the $\mathrm{CO}$ removal, but it also contributes to a higher $\mathrm{H}_{2}$ consumption. $\mathrm{H}_{2}$ is lost mainly by the formation of water and $\mathrm{CH}_{4}$, where the occurrence of $\mathrm{CO}_{2}$ methanation affected the $\mathrm{CO}$ removal differently. Over $\mathrm{CeO}_{2}-\mathrm{Al}_{2} \mathrm{O}_{3}$ and $\mathrm{CeO}_{2}-\mathrm{SiO}_{2}$, methanation seems to improve $\mathrm{CO}$ removal because the CO-PROX product, $\mathrm{CO}_{2}$, is constantly consumed to produce $\mathrm{CH}_{4}$. On the contrary, methanation has a negative effect on $\mathrm{CeO}_{2}$ and $\mathrm{La}_{2} \mathrm{O}_{3}$ because the formed $\mathrm{CH}_{4}$ favors carbon deposition.

Differences among the catalysts were evaluated by several characterization techniques. DRIFTS spectra of $\mathrm{CO}$ adsorption showed that $\mathrm{CeO}_{2}$ has a superior activity because it favors the formation of $\mathrm{C}-\mathrm{O}^{*}$ and $\mathrm{OH}^{-}$intermediates, but it promotes the formation of carbon deposits that lead to its deactivation. Similarly, TPR showed that $\mathrm{ZrO}_{2}$ has a high interaction with active metals $(\mathrm{Au}-\mathrm{Cu})$, which makes it active but less selective, favoring a high $\mathrm{H}_{2}$ oxidation. In addition, the low OSC of $\mathrm{Al}_{2} \mathrm{O}_{3}$ and $\mathrm{SiO}_{2}$, and the lower surface area of $\mathrm{Fe}_{2} \mathrm{O}_{3}$ and $\mathrm{La}_{2} \mathrm{O}_{3}$ make these metal oxides less active. Regarding dual supports, the inclusion of a second metal oxide weakens the interaction of $\mathrm{CeO}_{2}$ with the active metals, reducing activity. However, dual metal oxides are more selective and stable than single $\mathrm{CeO}_{2}$ because they mitigate the excess of $\mathrm{C}-\mathrm{O}^{*}$ species, as was observed by DRIFTS; specifically, $\mathrm{CeO}_{2}-\mathrm{SiO}_{2}$ mitigates the formation of stable carbon deposits that deactivate the catalyst. Thus, $\mathrm{AuCu} / \mathrm{CeO}_{2}$ was identified as a promising catalyst for carrying out the $\mathrm{CO}$ removal from a syngas using just one catalytic reactor, but improvements in $\mathrm{CeO}_{2}$ stability are still required. Therefore, the use of dual supports (e.g., $\mathrm{CeO}_{2}-\mathrm{SiO}_{2}$ ) could be a strategy to overcome single $\mathrm{CeO}_{2}$ deficiencies. Thus, the development of more compact systems for the purification of $\mathrm{H}_{2}$ suitable for FC implicitly promotes greater $\mathrm{H}_{2}$ consumption. The results of this work aim to contribute to the development and establishment of sustainable energies based on $\mathrm{H}_{2}$. 
Author Contributions: All the authors contributed to the development, writing, and review of this work.

Funding: This research was funded by Colciencias (Francisco Jose de Caldas Fund) and Universidad de La Sabana through the projects with code ING-163, ING-166, and ING-221 (Colciencias contracts 0608-2013, 174-2016 and 548-2019).

Acknowledgments: B. Cifuentes acknowledges Colciencias for the doctoral scholarship (grant number 727-2015). F. Bustamante acknowledges the support of the Environmental Catalysis Research Group of Universidad de Antioquia.

Conflicts of Interest: There are no conflicts of interest to declare.

\section{Appendix A}
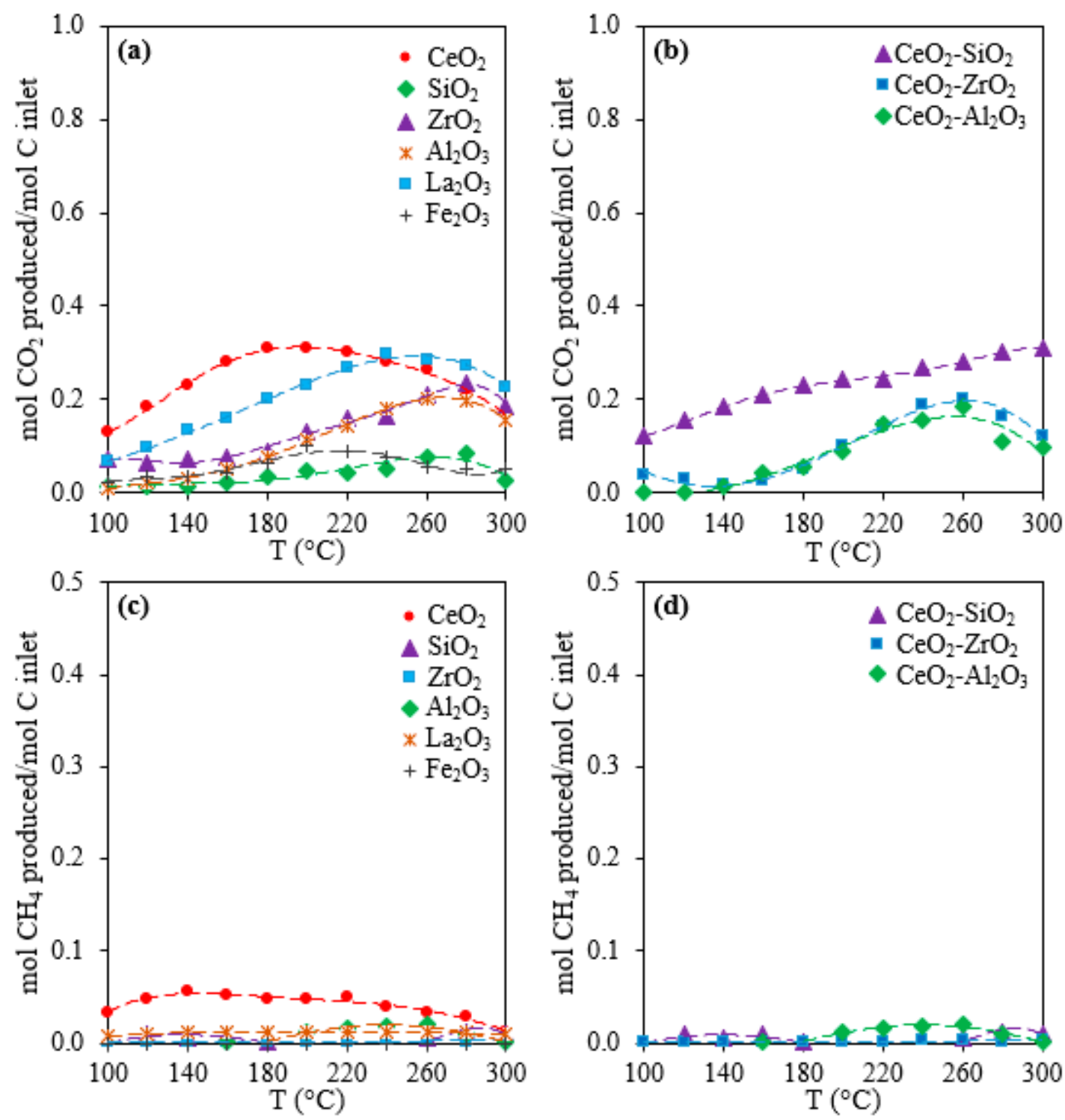

Figure A1. (a,b) $\mathrm{CO}_{2}$ and $\mathrm{CH}_{4}(\mathbf{c}, \mathbf{d})$ production in the $\mathrm{CO}$ cleanup reactor with simple and dual supports. Syngas composition: $8.4 \% \mathrm{H}_{2}, 2.2 \% \mathrm{CO}, 0.6 \% \mathrm{CO}_{2}, 0.3 \% \mathrm{CH}_{4}, 1.6 \% \mathrm{H}_{2} \mathrm{O}$, and Ar. $\lambda=1.8$. Reaction conditions: $\mathrm{SV}=6.5 \pm 0.2 \mathrm{~L} / \mathrm{g}_{\mathrm{cat}}{ }^{*} \mathrm{~min} ; 0.050 \mathrm{~g}$ of catalyst and $0.250 \mathrm{~g}$ of inert quartz. 

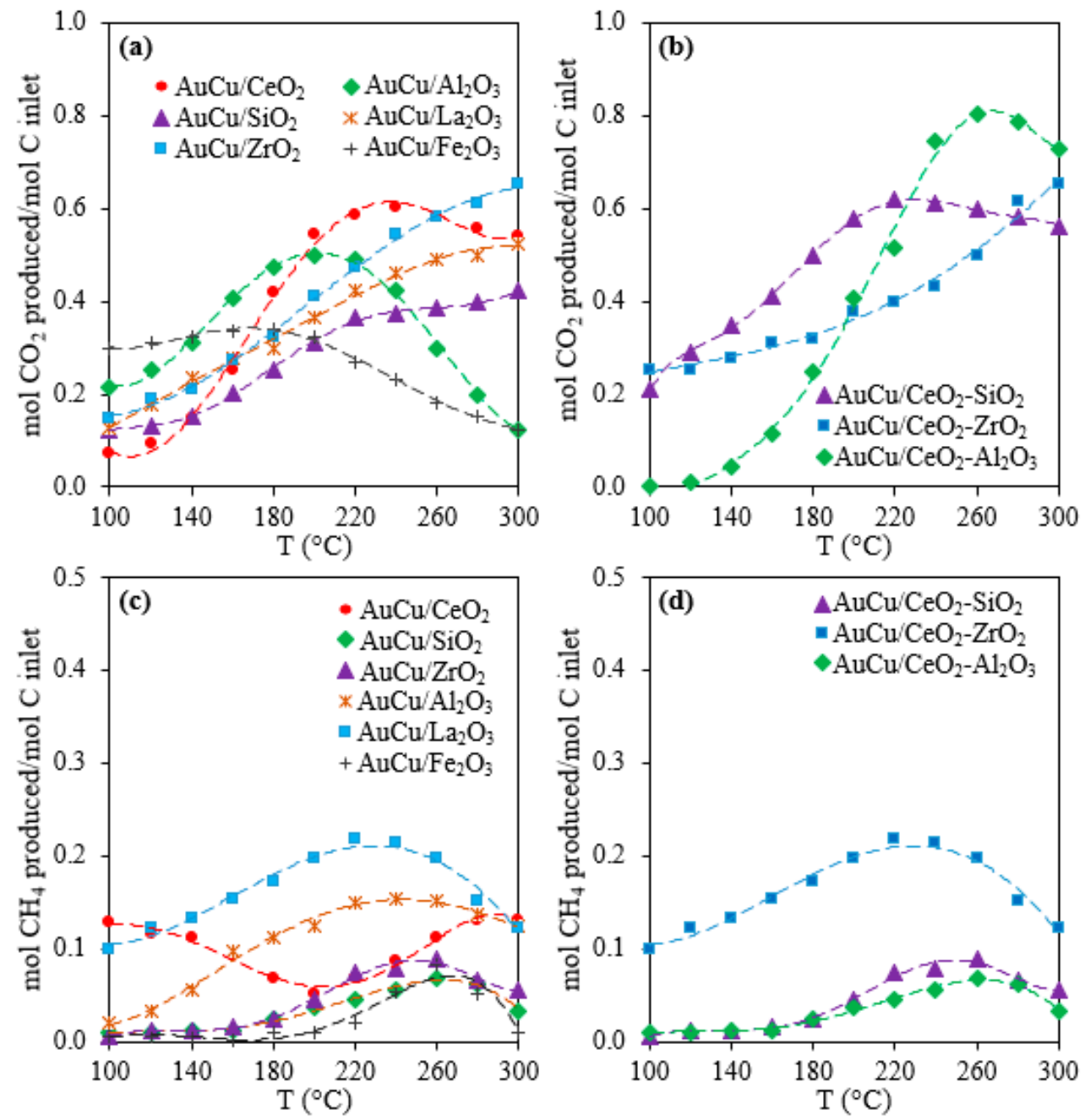

Figure A2. (a,b) $\mathrm{CO}_{2}$ and $\mathrm{CH}_{4}(\mathbf{c}, \mathbf{d})$ production in the $\mathrm{CO}$ cleanup reactor with $\mathrm{Au}-\mathrm{Cu}$ catalysts supported on simple and dual supports. Syngas composition: $8.4 \% \mathrm{H}_{2}, 2.2 \% \mathrm{CO}, 0.6 \% \mathrm{CO}_{2}, 0.3 \% \mathrm{CH}_{4}$, $1.6 \% \mathrm{H}_{2} \mathrm{O}$, and Ar. $\lambda=1.8$. Reaction conditions: $\mathrm{SV}=6.5 \pm 0.2 \mathrm{~L} / \mathrm{gcat}^{*} \mathrm{~min} ; 0.050 \mathrm{~g}$ of catalyst and $0.250 \mathrm{~g}$ of inert quartz.

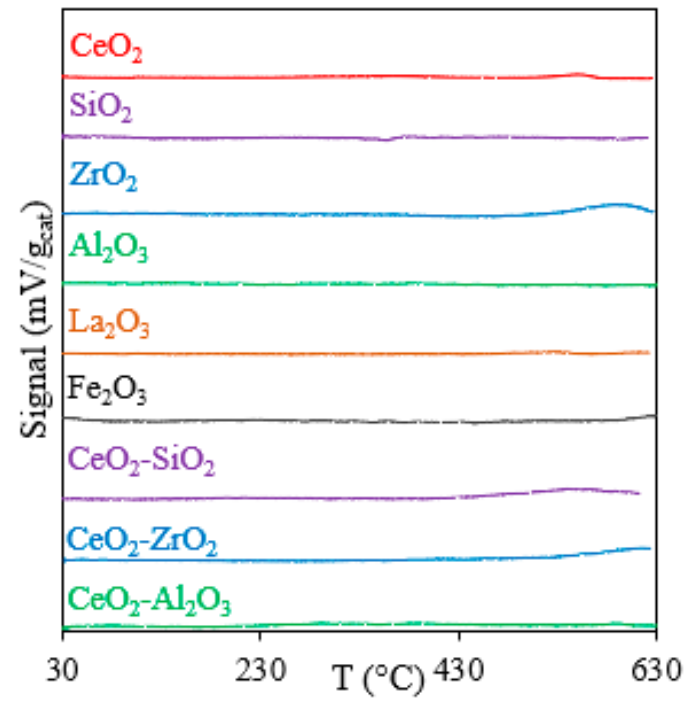

Figure A3. $\mathrm{H}_{2}$-TPR profiles of bare supports evaluated in the $\mathrm{CO}$ removal from an actual syngas. 


\section{Appendix B}

Table A1. Surface area, OSC, OSCC, and thermogravimetric analysis (TGA) results of single and dual supports.

\begin{tabular}{|c|c|c|c|c|c|c|}
\hline \multirow{2}{*}{ Support } & \multicolumn{2}{|c|}{ BET Surface Area ( $\mathrm{m}^{2} /$ gcat) } & \multirow{2}{*}{$\begin{array}{l}\text { OSC in Fresh Samples at } \\
300^{\circ} \mathrm{C}\left(\mu \mathrm{mol} \mathrm{O}_{2} / \text { gcat }\right)\end{array}$} & \multirow{2}{*}{ 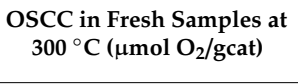 } & \multicolumn{2}{|c|}{ Weight Loss (\%) } \\
\hline & Fresh & Used & & & Fresh & Used \\
\hline $\mathrm{CeO}_{2}$ & 52.4 & 55.4 & 61 & 135 & 1.1 & 0.6 \\
\hline $\mathrm{SiO}_{2}$ & 466.5 & 410.6 & 41 & 49 & 1.4 & 1.1 \\
\hline $\mathrm{ZrO}_{2}$ & 51.6 & 44.9 & 55 & 99 & 1.6 & 0.6 \\
\hline $\mathrm{Al}_{2} \mathrm{O}_{3}$ & 96 & 68.6 & 36 & 55 & 1.7 & 0.2 \\
\hline $\mathrm{La}_{2} \mathrm{O}_{3}$ & 14.1 & 15.3 & 21 & 68 & 5.5 & 2.1 \\
\hline $\mathrm{Fe}_{2} \mathrm{O}_{3}$ & 38.1 & 36.7 & 5 & 16 & 0.7 & 0.8 \\
\hline $\mathrm{CeO}_{2}-\mathrm{SiO}_{2}$ & 163.2 & 155.2 & 54 & 105 & -2.7 & 1.8 \\
\hline $\mathrm{CeO}_{2}-\mathrm{ZrO}_{2}$ & 44.3 & 40.5 & 46 & 110 & 0.2 & 2.0 \\
\hline $\mathrm{CeO}_{2}-\mathrm{Al}_{2} \mathrm{O}_{3}$ & 72.7 & 69.1 & 41 & 120 & 2.0 & 1.0 \\
\hline
\end{tabular}

Table A2. Reviewed articles for the selection of supports evaluated in the CO removal.

\begin{tabular}{|c|c|c|c|c|c|}
\hline Date & Active Metals & Metal Oxide I & Metal Oxide II & Journal & Digital Object Identifier (DOI) \\
\hline 2012 & $\mathrm{CuO}$ & $\mathrm{Fe}_{2} \mathrm{O}_{3}$ & - & Chemical Engineering Journal & 10.1016/j.cej.2012.01.017 \\
\hline 2012 & $\mathrm{Pt}$ & Other & - & Electrochimica Acta & 10.1016/j.electacta.2012.04.150 \\
\hline 2012 & - & $\mathrm{Fe}_{2} \mathrm{O}_{3}$ & - & Applied Surface Science & 10.1016/j.apsusc.2011.10.092 \\
\hline 2012 & - & $\mathrm{NiO}_{2}$ & - & $\begin{array}{c}\text { Journal of Molecular Catalysis } \\
\text { A: Chemical }\end{array}$ & 10.1016/j.molcata.2012.05.001 \\
\hline 2013 & $\mathrm{Ni}, \mathrm{Co}$ & $\mathrm{Co}_{3} \mathrm{O}_{4}$ & - & Journal of Alloys and Compounds & 10.1016/j.jallcom.2013.04.053 \\
\hline 2013 & $\mathrm{CuO}$ & $\mathrm{TiO}_{2}$ & $\mathrm{Al}_{2} \mathrm{O}_{3}$ & Surface and Coatings Technology & $10.1016 / j$.surfcoat.2012.10.031 \\
\hline 2013 & Co & $\mathrm{Fe} 2 \mathrm{O} 3$ & - & Chemical Engineering Journal & 10.1016/j.ces.2013.02.002 \\
\hline 2014 & Co & $\mathrm{MgO}$ & - & $\begin{array}{c}\text { Process Safety and } \\
\text { Environmental Protection }\end{array}$ & 10.1016/j.psep.2013.12.003 \\
\hline 2014 & $\mathrm{Pt}$ & $\mathrm{CeO}_{2}$ & - & Chemical Engineering Journal & 10.1016/j.cej.2014.06.058 \\
\hline 2014 & $\mathrm{Pd}$ & $\mathrm{Fe}_{2} \mathrm{O}_{3}$ & - & Journal of Catalysis & 10.1016/j.jcat.2014.06.019 \\
\hline 2014 & $\mathrm{Ag}$ & Zeolite & - & Fuel & 10.1016/j.fuel.2014.07.011 \\
\hline 2014 & $\mathrm{Au}$ & $\mathrm{NiO}_{2}$ & - & Applied Catalysis A: General & 10.1016/j.apcata.2014.02.003 \\
\hline 2014 & $\mathrm{CuO}$ & $\mathrm{SiO}_{2}$ & $\mathrm{CeO}_{2}$ & $\begin{array}{l}\text { Journal of Environmental } \\
\text { Chemical Engineering }\end{array}$ & 10.1016/j.jece.2014.03.021 \\
\hline 2015 & $\mathrm{Co}, \mathrm{Fe}, \mathrm{Cr}$ & $\mathrm{CeO}_{2}$ & - & International Journal of Hydrogen Energy & 10.1016/j.ijhydene.2015.03.044 \\
\hline 2015 & - & $\mathrm{Co}_{3} \mathrm{O}_{4}$ & - & Applied Catalysis A: General & 10.1016/j.apcata.2014.10.024 \\
\hline 2015 & $\mathrm{CuO}$ & $\mathrm{Fe}_{2} \mathrm{O}_{3}$ & - & Chinese Journal of Catalysis & $10.1016 / \mathrm{S} 1872-2067(15) 60922-6$ \\
\hline 2015 & $\mathrm{Au}$ & Zeolite & - & Catalysis Communications & 10.1016/j.catcom.2015.06.018 \\
\hline 2015 & $\mathrm{Pt}$ & $\mathrm{CeO}_{2}$ & - & Catalysis Today & 10.1016/j.cattod.2014.12.038 \\
\hline 2015 & $\mathrm{Au}, \mathrm{Cu}$ & $\mathrm{CeO}_{2}$ & $\mathrm{ZrO}_{2}$ & Catalysis Today & 10.1016/j.cattod.2014.08.035 \\
\hline 2015 & - & $\mathrm{PtO} 2$ & - & Applied Surface Science & 10.1016/j.apsusc.2015.03.108 \\
\hline 2015 & $\mathrm{CuO}$ & $\mathrm{CeO}_{2}$ & $\mathrm{ZrO}_{2}$ & $\begin{array}{l}\text { Journal of Industrial and } \\
\text { Engineering Chemistry }\end{array}$ & 10.1016/j.jiec.2015.06.038 \\
\hline 2015 & - & $\mathrm{MnO}_{2}$ & $\mathrm{CeO}_{2}$ & Applied Catalysis B: Environmental & 10.1016/j.apcatb.2014.06.038 \\
\hline 2016 & $\mathrm{Pd}$ & $\mathrm{Fe}_{2} \mathrm{O}_{3}$ & - & $\begin{array}{l}\text { Journal of Environmental } \\
\text { Chemical Engineering }\end{array}$ & 10.1016/j.jece.2016.10.019 \\
\hline 2016 & - & $\mathrm{CeO}_{2}$ & $\mathrm{ZrO}_{2}$ & Applied Catalysis B: Environmental & 10.1016/j.apcatb.2016.02.023 \\
\hline 2016 & $\mathrm{Au}$ & $\mathrm{Zn}_{2} \mathrm{SnO}_{4}$ & - & Chinese Journal of Catalysis & $10.1016 / \mathrm{S} 1872-2067(16) 62468-3$ \\
\hline 2016 & - & $\mathrm{Co}_{3} \mathrm{O}_{4}$ & - & Catalysis Communications & 10.1016/j.catcom.2016.08.020 \\
\hline 2016 & $\mathrm{Au}$ & $\mathrm{CeO}_{2}$ & - & Applied Catalysis B: Environmental & 10.1016/j.apcatb.2016.02.025 \\
\hline 2016 & $\mathrm{Pd}$ & $\mathrm{CeO}_{2}$ & - & $\begin{array}{c}\text { Journal of Molecular Catalysis } \\
\text { A: Chemical }\end{array}$ & 10.1016/j.molcata.2016.08.035 \\
\hline 2016 & - & $\mathrm{SiO}_{2}$ & $\mathrm{Al}_{2} \mathrm{O}_{3}$ & $\begin{array}{l}\text { Journal of Molecular Graphics and } \\
\text { Modelling }\end{array}$ & 10.1016/j.jmgm.2016.08.005 \\
\hline 2016 & $\mathrm{Ag}$ & $\mathrm{SiO}_{2}$ & - & Catalysis Today & 10.1016/j.cattod.2016.05.033 \\
\hline 2016 & - & $\mathrm{PdO}$ & - & Surface Science & 10.1016/j.susc. 2015.08 .043 \\
\hline 2016 & - & $\mathrm{Co}_{3} \mathrm{O}_{4}$ & - & Applied Catalysis A: General & 10.1016/j.apcata.2016.03.027 \\
\hline 2016 & $\mathrm{CuO}$ & $\mathrm{TiO}_{2}$ & - & Catalysis Communications & 10.1016/j.catcom.2016.02.001 \\
\hline 2016 & $\mathrm{Pt}$ & $\mathrm{CeO}_{2}$ & - & Applied Catalysis B: Environmental & 10.1016/j.apcatb.2016.01.056 \\
\hline 2016 & $\mathrm{CuO}$ & $\mathrm{MnO}_{2}$ & - & $\begin{array}{l}\text { Journal of Molecular Catalysis } \\
\text { A: Chemical }\end{array}$ & 10.1016/j.molcata.2016.08.024 \\
\hline 2016 & $\mathrm{CuO}$ & Peroskita & - & Applied Clay Science & 10.1016/j.clay.2015.08.034 \\
\hline 2016 & $\mathrm{Pd}$ & $\mathrm{ZnO}$ & - & Catalysis Today & 10.1016/j.cattod.2015.05.021 \\
\hline 2016 & - & $\mathrm{Fe}_{2} \mathrm{O}_{3}$ & - & Chemical Engineering Journal & 10.1016/j.cej.2016.04.136 \\
\hline 2016 & $\mathrm{Au}$ & $\mathrm{TiO}_{2}$ & - & Catalysis Today & 10.1016/j.cattod.2015.09.040 \\
\hline 2016 & $\mathrm{Au}$ & $\mathrm{Fe}_{2} \mathrm{O}_{3}$ & $\mathrm{CeO}_{2}$ & Catalysis Today & 10.1016/j.cattod.2016.05.059 \\
\hline 2016 & - & $\mathrm{Co}_{3} \mathrm{O}_{4}$ & - & Materials Letters & 10.1016/j.matlet.2016.06.108 \\
\hline 2016 & - & $\mathrm{Co}_{3} \mathrm{O}_{4}$ & - & Chinese Journal of Catalysis & 10.1016/S1872-2067(15)60969-X \\
\hline 2016 & $\mathrm{Au}$ & $\mathrm{TiO}_{2}$ & - & Applied Surface Science & 10.1016/j.apsusc.2016.01.285 \\
\hline 2016 & - & $\mathrm{Fe}_{2} \mathrm{O}_{3}$ & - & $\begin{array}{c}\text { Journal of Molecular Catalysis } \\
\text { A: Chemical }\end{array}$ & 10.1016/j.molcata.2016.01.003 \\
\hline 2016 & $\mathrm{Au}$ & Other & - & Journal of Colloid and Interface Science & 10.1016/j.jcis.2016.06.072 \\
\hline 2016 & $\mathrm{Au}$ & $\mathrm{LaPO}_{4}$ & - & $\begin{array}{c}\text { Journal of the Taiwan Institute of } \\
\text { Chemical Engineers }\end{array}$ & 10.1016/j.jtice.2016.01.016 \\
\hline 2016 & $\mathrm{Pt}$ & $\mathrm{Al}_{2} \mathrm{O}_{3}$ & - & International Journal of Hydrogen Energy & 10.1016/j.ijhydene.2016.08.170 \\
\hline 2016 & $\mathrm{Pt}$ & Other & - & Surface Science & 10.1016/j.susc.2015.08.024 \\
\hline
\end{tabular}


Table A2. Cont.

\begin{tabular}{|c|c|c|c|c|c|}
\hline Date & Active Metals & Metal Oxide I & Metal Oxide II & Journal & Digital Object Identifier (DOI) \\
\hline 2017 & $\mathrm{CuO}$ & $\mathrm{Nb}_{2} \mathrm{O}_{5}$ & - & Catalysis Communications & 10.1016/j.catcom.2017.04.008 \\
\hline 2017 & $\mathrm{Zn}, \mathrm{Pt}$ & $\mathrm{CeO}_{2}$ & - & Applied Catalysis B: Environmental & 10.1016/j.apcatb.2017.04.044 \\
\hline 2017 & $\mathrm{Pt}, \mathrm{Fe}$ & $\mathrm{Fe}_{2} \mathrm{O}_{3}$ & $\mathrm{Co}_{3} \mathrm{O}_{4}$ & Chinese Journal of Catalysis & $10.1016 / S 1872-2067(17) 62838-9$ \\
\hline 2017 & $\mathrm{CuO}$ & $\mathrm{MnO}_{2}$ & $\mathrm{CeO}_{2}$ & Catalysis Communications & 10.1016/j.catcom.2017.05.016 \\
\hline 2017 & $\mathrm{Pt}$ & $\mathrm{MnO}_{2}$ & - & Journal of Electroanalytical Chemistry & 10.1016/j.jelechem.2016.09.031 \\
\hline 2017 & $\mathrm{Au}$ & $\mathrm{LaPO}_{4}$ & - & Chinese Journal of Chemical Engineering & 10.1016/j.cjche.2017.08.008 \\
\hline 2017 & $\mathrm{Fe}, \mathrm{Mn}$ & $\mathrm{CeO}_{2}$ & - & Catalysis Today & 10.1016/j.cattod.2016.11.046 \\
\hline 2017 & $\mathrm{Mn}$ & $\mathrm{Co}_{3} \mathrm{O}_{4}$ & - & Solid State Sciences & 10.1016/j.solidstatesciences.2017.07.006 \\
\hline 2017 & $\mathrm{Mn}$ & $\mathrm{Co}_{3} \mathrm{O}_{4}$ & - & Fuel & 10.1016/j.fuel.2017.04.140 \\
\hline 2017 & $\mathrm{Au}$ & $\mathrm{CeO}_{2}$ & - & Applied Surface Science & 10.1016/j.apsusc.2017.04.158 \\
\hline 2017 & - & $\mathrm{MgO}$ & - & Applied Catalysis B: Environmental & 10.1016/j.apcatb.2016.11.043 \\
\hline 2017 & $\mathrm{CuO}$ & $\mathrm{CeO}_{2}$ & Zeolite & Microporous and Mesoporous Materials & 10.1016/j.micromeso.2017.02.016 \\
\hline 2017 & - & Zeolite & - & Applied Catalysis B: Environmental & 10.1016/j.apcatb.2017.06.083 \\
\hline 2017 & Co & $\mathrm{ZnO}$ & - & Ceramics International & 10.1016/j.ceramint.2017.06.157 \\
\hline 2017 & $\mathrm{Pd}$ & $\mathrm{TiO}_{2}$ & $\mathrm{SnO}_{2}$ & Applied Catalysis B: Environmental & 10.1016/j.apcatb.2017.02.017 \\
\hline 2017 & $\mathrm{Pd}$ & $\mathrm{Fe}_{2} \mathrm{O}_{3}$ & - & Fuel Processing Technology & 10.1016/j.fuproc.2017.02.037 \\
\hline 2017 & $\mathrm{CuO}$ & $\mathrm{CeO}_{2}$ & - & Journal of Power Sources & 10.1016/j.jpowsour.2017.01.127 \\
\hline 2017 & $\mathrm{Mn}$ & $\mathrm{CeO}_{2}$ & - & Applied Catalysis B: Environmental & 10.1016/j.apcatb.2017.03.049 \\
\hline 2017 & Co & $\mathrm{Co}_{3} \mathrm{O}_{4}$ & - & Chemical Physics Letters & 10.1016/j.cplett.2017.02.085 \\
\hline 2017 & $\mathrm{Au}$ & $\mathrm{TiO}_{2}$ & - & Catalysis Today & 10.1016/j.cattod.2016.05.056 \\
\hline 2017 & $\mathrm{CuO}$ & $\mathrm{CeO}_{2}$ & - & International Journal of Hydrogen Energy & 10.1016/j.ijhydene.2017.02.088 \\
\hline 2017 & $\mathrm{CuO}$ & $\mathrm{CeO}_{2}$ & - & Journal of Rare Earths & 10.1016/j.jre.2017.05.015 \\
\hline 2017 & $\mathrm{Pd}$ & $\mathrm{Al}_{2} \mathrm{O}_{3}$ & - & Applied Catalysis B: Environmental & 10.1016/j.apcatb.2017.02.038 \\
\hline 2017 & $\mathrm{Pt}$ & $\mathrm{TiO}_{2}$ & - & Molecular Catalysis & 10.1016/j.mcat.2017.01.014 \\
\hline 2017 & - & $\mathrm{CeO}_{2}$ & Other & Catalysis Today & 10.1016/j.cattod.2017.06.017 \\
\hline 2017 & - & $\mathrm{Al}_{2} \mathrm{O}_{3}$ & $\mathrm{SnO}_{2}$ & Applied Surface Science & 10.1016/j.apsusc.2017.01.058 \\
\hline 2017 & $\mathrm{Ag}$ & Zeolite & - & Fuel & 10.1016/j.fuel.2016.10.037 \\
\hline 2017 & $\mathrm{Au}$ & $\mathrm{TiO}_{2}$ & - & Applied Surface Science & 10.1016/j.apsusc.2016.10.076 \\
\hline 2017 & - & Carbon & - & Molecular Catalysis & 10.1016/j.molcata.2016.12.007 \\
\hline 2017 & $\mathrm{Ag}$ & $\mathrm{SiO}_{2}$ & - & Microporous and Mesoporous Materials & 10.1016/j.micromeso.2017.01.016 \\
\hline 2017 & $\mathrm{Pd}, \mathrm{Rh}$ & $\mathrm{Al}_{2} \mathrm{O}_{3}$ & - & Catalysis Today & 10.1016/j.cattod.2016.10.010 \\
\hline 2017 & $\mathrm{Au}, \mathrm{Cu}$ & $\mathrm{SiO}_{2}$ & - & Catalysis Today & 10.1016/j.cattod.2016.08.003 \\
\hline 2017 & $\mathrm{Pd}$ & $\mathrm{CeO}_{2}$ & $\mathrm{MnO}$ & Applied Catalysis B: Environmental & 10.1016/j.apcatb.2017.01.020 \\
\hline 2017 & - & $\mathrm{CeO}_{2}$ & - & Catalysis Today & 10.1016/j.cattod.2016.04.016 \\
\hline 2017 & $\mathrm{Pd}$ & $\mathrm{Co}_{3} \mathrm{O}_{4}$ & - & Applied Catalysis A: General & 10.1016/j.apcata.2016.12.021 \\
\hline 2017 & $\mathrm{Pt}$ & $\mathrm{CeO}_{2}$ & - & Applied Catalysis A: General & 10.1016/j.apcata.2017.08.012 \\
\hline 2017 & $\mathrm{Mn}$ & $\mathrm{Co}_{3} \mathrm{O}_{4}$ & - & Solid State Sciences & 10.1016/j.solidstatesciences.2017.07.006 \\
\hline 2017 & $\mathrm{Ni}$ & $\mathrm{ZrO}_{2}$ & - & Applied Catalysis A: General & 10.1016/j.apcata.2017.02.001 \\
\hline 2018 & - & $\mathrm{SiO}_{2}$ & $\mathrm{Co}_{3} \mathrm{O}_{4}$ & Microporous and Mesoporous Materials & 10.1016/j.micromeso.2017.07.016 \\
\hline 2018 & $\mathrm{Pt}$ & $\mathrm{Fe}_{2} \mathrm{O}_{3}$ & - & Applied Catalysis A: General & 10.1016/j.apcata.2018.09.014 \\
\hline 2018 & $\mathrm{Pd}$ & $\mathrm{SiO}_{2}$ & $\mathrm{Al}_{2} \mathrm{O}_{3}$ & Applied Catalysis B: Environmental & 10.1016/j.apcatb.2018.06.059 \\
\hline 2018 & $\mathrm{Cu}$ & $\mathrm{CeO}_{2}$ & - & Catalysis Today & 10.1016/j.cattod.2018.10.037 \\
\hline 2018 & $\mathrm{Cu}-\mathrm{Ni}$ & $\mathrm{CeO}_{2}$ & $\mathrm{Al}_{2} \mathrm{O}_{3}$ & International Journal of Hydrogen Energy & 10.1016/j.ijhydene.2018.12.127 \\
\hline 2018 & $\mathrm{Ru}$ & $\mathrm{TiO}_{2}$ & $\mathrm{ZrO}_{2}$ & International Journal of Hydrogen Energy & 10.1016/j.ijhydene.2018.10.061 \\
\hline 2018 & $\mathrm{Ni}$ & $\mathrm{ZrO}_{2}$ & - & International Journal of Hydrogen Energy & 10.1016/j.ijhydene.2018.06.173 \\
\hline 2018 & - & $\mathrm{ZrO}_{2}$ & - & Applied Catalysis B: Environmental & 10.1016/j.apcatb.2018.03.001 \\
\hline 2018 & $\mathrm{Ni}$ & $\mathrm{ZrO}_{2}$ & - & Applied Catalysis B: Environmental & 10.1016/j.apcatb.2018.06.045 \\
\hline 2019 & $\mathrm{Au}$ & $\mathrm{TiO}_{2}$ & - & International Journal of Hydrogen Energy & 10.1016/j.ijhydene.2018.11.050 \\
\hline 2019 & $\mathrm{Cu}$ & $\mathrm{Co}_{3} \mathrm{O}_{4}$ & - & Molecular Catalysis & 10.1016/j.mcat.2019.01.020 \\
\hline 2019 & - & Other & - & Applied Catalysis B: Environmental & 10.1016/j.apcatb.2018.12.022 \\
\hline 2019 & $\mathrm{Pt}$ & Zeolite & - & Applied Catalysis A: General & 10.1016/j.apcata.2018.12.034 \\
\hline 2019 & $\mathrm{Ni}$ & $\mathrm{ZrO}_{2}$ & - & Applied Catalysis B: Environmental & 10.1016/j.apcatb.2018.11.024 \\
\hline
\end{tabular}

\section{References}

1. Zhang, K.; Jiang, X. An investigation of fuel variability effect on bio-syngas combustion using uncertainty quantification. Fuel 2018, 220, 283-295. [CrossRef]

2. Renzi, M.; Patuzzi, F.; Baratieri, M. Syngas feed of micro gas turbines with steam injection: Effects on performance, combustion and pollutants formation. Appl. Energy 2017, 206, 697-707. [CrossRef]

3. Rosa, A. Chapter 10-Hydrogen Production. In Fundamentals of Renewable Energy Processes, 3rd ed.; Academic Press: Cambridge, MA, USA, 2013; pp. 371-428.

4. Mohammed, H.; Al-Othman, A.; Nancarrow, P.; Tawalbeh, M.; El Haj Assad, M. Direct hydrocarbon fuel cells: A promising technology for improving energy efficiency. Energy 2019, 172, 207-219. [CrossRef]

5. Sengodan, S.; Lan, R.; Humphreys, J.; Du, D.; Xu, W.; Wang, H.; Tao, S. Advances in reforming and partial oxidation of hydrocarbons for hydrogen production and fuel cell applications. Renew. Sustain. Energy Rev. 2018, 82, 761-780. [CrossRef]

6. Cifuentes, B.; Hernández, M.; Monsalve, S.; Cobo, M. Hydrogen production by steam reforming of ethanol on a $\mathrm{RhPt} / \mathrm{CeO}_{2} / \mathrm{SiO}_{2}$ catalyst: Synergistic effect of the Si:Ce ratio on the catalyst performance. Appl. Catal. A Gen. 2016, 523, 283-293. [CrossRef] 
7. Xie, Y.; Wu, J.; Jing, G.; Zhang, H.; Zeng, S.; Tian, X.; Zou, X.; Wen, J.; Su, H.; Zhong, C.J.; et al. Structural origin of high catalytic activity for preferential $\mathrm{CO}$ oxidation over $\mathrm{CuO} / \mathrm{CeO}_{2}$ nanocatalysts with different shapes. Appl. Catal. B Environ. 2018, 239, 665-676. [CrossRef]

8. Kou, T.; Si, C.; Gao, Y.; Frenzel, J.; Wang, H.; Yan, X.; Bai, Q.; Eggeler, G.; Zhang, Z. Large-scale synthesis and catalytic activity of nanoporous $\mathrm{Cu}-\mathrm{O}$ system towards CO oxidation. RSC Adv. 2014, 4, 65004-65011. [CrossRef]

9. Kou, T.; Si, C.; Pinto, J.; Ma, C.; Zhang, Z. Dealloying assisted high-yield growth of surfactant-free $\langle 110\rangle$ highly active $\mathrm{Cu}$-doped $\mathrm{CeO}_{2}$ nanowires for low-temperature $\mathrm{CO}$ oxidation. Nanoscale 2017, 9, 8007-8014. [CrossRef]

10. Ashraf, M.A.; Ercolino, G.; Specchia, S.; Specchia, V. Final step for CO syngas clean-up: Comparison between CO-PROX and CO-SMET processes. Int. J. Hydrogen Energy 2014, 39, 18109-18119. [CrossRef]

11. Rossetti, I.; Compagnoni, M.; Torli, M. Process simulation and optimization of H2 production from ethanol steam reforming and its use in fuel cells. 2. Process analysis and optimization. Chem. Eng. J. 2015, 281, 1036-1044. [CrossRef]

12. Gubán, D.; Tompos, A.; Bakos, I.; Vass, Á.; Pászti, Z.; Szabó, E.G.; Sajó, I.E.; Borbáth, I. Preparation of CO-tolerant anode electrocatalysts for polymer electrolyte membrane fuel cells. Int. J. Hydrogen Energy 2017, 42, 13741-13753. [CrossRef]

13. Narayanan, H.; Basu, S. Regeneration of CO poisoned Pt black anode catalyst in PEMFC using break-in procedure and $\mathrm{KMnO} 4$ solution. Int. J. Hydrogen Energy 2017, 42, 23814-23820. [CrossRef]

14. Devrim, Y.; Albostan, A.; Devrim, H. Experimental investigation of CO tolerance in high temperature PEM fuel cells. Int. J. Hydrogen Energy 2018, 43, 18672-18681. [CrossRef]

15. Kugai, J.; Fox, E.B.; Song, C. Kinetic characteristics of oxygen-enhanced water gas shift on CeO2-supported Pt-Cu and Pd-Cu bimetallic catalysts. Appl. Catal. A Gen. 2015, 497, 31-41. [CrossRef]

16. Xu, G.; Zhang, Z.G. Preferential CO oxidation on Ru/Al2O3 catalyst: An investigation by considering the simultaneously involved methanation. J. Power Sources 2006, 157, 64-77. [CrossRef]

17. Reina, T.R.; Ivanova, S.; Laguna, O.H.; Centeno, M.A.; Odriozola, J.A. WGS and CO-PrOx reactions using gold promoted copper-ceria catalysts: "bulk $\mathrm{CuO}-\mathrm{CeO}_{2}$ vs. $\mathrm{CuO}-\mathrm{CeO}_{2} / \mathrm{Al}_{2} \mathrm{O}_{3}$ with low mixed oxide content". Appl. Catal. B Environ. 2016, 197, 67-72. [CrossRef]

18. Wang, F.; Zhang, J.-C.; Li, W.-Z.; Chen, B.-H. Coke-resistant $\mathrm{Au}-\mathrm{Ni} / \mathrm{MgAl}_{2} \mathrm{O}_{4}$ catalyst for direct methanation of syngas. J. Energy Chem. 2019, 39, 198-207. [CrossRef]

19. Reina, T.R.R.; Ivanova, S.; Centeno, M.A.A.; Odriozola, J.A.A. Catalytic screening of $\mathrm{Au} / \mathrm{CeO} 2-\mathrm{MOx}_{2} / \mathrm{Al}_{2} \mathrm{O}_{3}$ $(\mathrm{M}=\mathrm{La}, \mathrm{Ni}, \mathrm{Cu}, \mathrm{Fe}, \mathrm{Cr}, \mathrm{Y})$ in the CO-PrOx reaction. Int. J. Hydrogen Energy 2015, 40, 1782-1788. [CrossRef]

20. Cifuentes, B.; Bustamante, F.; Conesa, J.A.; Córdoba, L.F.; Cobo, M. Fuel-cell grade hydrogen production by coupling steam reforming of ethanol and carbon monoxide removal. Int. J. Hydrogen Energy 2018, 43, 17216-17229. [CrossRef]

21. Yao, X.; Gao, F.; Dong, L. The application of incorporation model in $\gamma-\mathrm{Al}_{2} \mathrm{O}_{3}$-supported single and dual metal oxide catalysts: A review. Cuihua Xuebao/Chin. J. Catal. 2013, 34, 1975-1985. [CrossRef]

22. MacIel, C.G.; Profeti, L.P.R.; Assaf, E.M.; Assaf, J.M. Hydrogen purification for fuel cell using $\mathrm{CuO} / \mathrm{CeO}_{2}-\mathrm{Al}_{2} \mathrm{O}_{3}$ catalyst. J. Power Sources 2011, 196, 747-753. [CrossRef]

23. Águila, G.; Gracia, F.; Araya, P. CuO and $\mathrm{CeO}_{2}$ catalysts supported on $\mathrm{Al}_{2} \mathrm{O}_{3}, \mathrm{ZrO}_{2}$, and $\mathrm{SiO}_{2}$ in the oxidation of CO at low temperature. Appl. Catal. A Gen. 2008, 343, 16-24. [CrossRef]

24. Zhao, Z.; Lin, X.; Jin, R.; Dai, Y.; Wang, G. High catalytic activity in CO PROX reaction of low cobalt-oxide loading catalysts supported on nano-particulate $\mathrm{CeO}_{2}-\mathrm{ZrO}_{2}$ oxides. Catal. Commun. 2011, 12, 1448-1451. [CrossRef]

25. Moretti, E.; Rodríguez-Aguado, E.; Molina, A.I.; Rodríguez-Castellón, E.; Talon, A.; Storaro, L. Sustainable photo-assisted $\mathrm{CO}$ oxidation in $\mathrm{H}_{2}$-rich stream by simulated solar light response of Au nanoparticles supported on $\mathrm{TiO}_{2}$. Catal. Today 2018, 304, 135-142. [CrossRef]

26. Li, S.; Tang, H.; Gong, D.; Ma, Z.; Liu, Y. Loading $\mathrm{Ni} / \mathrm{La}_{2} \mathrm{O}_{3}$ on $\mathrm{SiO}_{2}$ for $\mathrm{CO}$ methanation from syngas. Catal. Today 2017, 297, 298-307. [CrossRef]

27. Liu, S.; Wu, X.; Weng, D.; Ran, R. Ceria-based catalysts for soot oxidation: A review. J. Rare Earths 2015, 33, 567-590. [CrossRef]

28. Martínez, L.M.; Laguna, O.H.; López-Cartes, C.; Centeno, M.A. Synthesis and characterization of $\mathrm{Rh} / \mathrm{MnO}_{2}-\mathrm{CeO}_{2} / \mathrm{Al}_{2} \mathrm{O}_{3}$ catalysts for CO-PrOx reaction. Mol. Catal. 2017, 440, 9-18. [CrossRef] 
29. Gamboa-Rosales, N.K.; Ayastuy, J.L.; González-Marcos, M.P.; Gutiérrez-Ortiz, M.A. Effect of Au promoter in $\mathrm{CuO} / \mathrm{CeO}_{2}$ catalysts for the oxygen-assisted WGS reaction. Catal. Today 2011, 176, 63-71. [CrossRef]

30. Destro, P.; Marras, S.; Manna, L.; Colombo, M.; Zanchet, D. AuCu alloy nanoparticles supported on $\mathrm{SiO}_{2}$ : Impact of redox pretreatments in the catalyst performance in CO oxidation. Catal. Today 2017, 282, 105-110. [CrossRef]

31. Destro, P.; Kokumai, T.M.; Scarpellini, A.; Pasquale, L.; Manna, L.; Colombo, M.; Zanchet, D. The Crucial Role of the Support in the Transformations of Bimetallic Nanoparticles and Catalytic Performance. ACS Catal. 2017, 8, 1031-1037. [CrossRef]

32. Ayastuy, J.L.; Gurbani, A.; Gutiérrez-Ortiz, M.A. Effect of calcination temperature on catalytic properties of $\mathrm{Au} / \mathrm{Fe}_{2} \mathrm{O}_{3}$ catalysts in CO-PROX. Int. J. Hydrogen Energy 2016, 41, 19546-19555. [CrossRef]

33. Lakshmanan, P.; Park, E. Preferential CO Oxidation in $\mathrm{H}_{2}$ over $\mathrm{Au} / \mathrm{La}_{2} \mathrm{O}_{3} / \mathrm{Al}_{2} \mathrm{O}_{3}$ Catalysts: The Effect of the Catalyst Reduction Method. Catalysts 2018, 8, 183-193. [CrossRef]

34. Córdoba, L.F.; Martínez-Hernández, A. Preferential oxidation of CO in excess of hydrogen over $\mathrm{Au} / \mathrm{CeO}_{2}-\mathrm{ZrO}_{2}$ catalysts. Int. J. Hydrogen Energy 2015, 40, 16192-16201. [CrossRef]

35. Arévalo, J.D.; Martinez-Hernández, Á.; Vargas, J.C.; Córdoba, L.F. Hydrogen Production and Purification by Bioethanol Steam Reforming and Preferential Oxidation of CO. Tecciencia 2018, 13, 55-64.

36. Chen, Z.; Pursell, C.J.; Chandler, B.D.; Saavedra, J.; Whittaker, T.; Rioux, R.M. Controlling activity and selectivity using water in the Au-catalysed preferential oxidation of $\mathrm{CO}$ in $\mathrm{H}_{2}$. Nat. Chem. 2016, 8, 584-589.

37. Dasireddy, V.D.B.C.; Valand, J.; Likozar, B. PROX reaction of $\mathrm{CO}$ in $\mathrm{H}_{2} / \mathrm{H}_{2} \mathrm{O} / \mathrm{CO}_{2}$ Water-Gas Shift (WGS) feedstocks over $\mathrm{Cu}-\mathrm{Mn} / \mathrm{Al}_{2} \mathrm{O}_{3}$ and $\mathrm{Cu}-\mathrm{Ni} / \mathrm{Al}_{2} \mathrm{O}_{3}$ catalysts for fuel cell applications. Renew. Energy 2018, 116, 75-87. [CrossRef]

38. Zhan, W.; Wang, J.; Wang, H.; Zhang, J.; Liu, X.; Zhang, P.; Chi, M.; Guo, Y.; Guo, Y.; Lu, G.; et al. Crystal Structural Effect of AuCu Alloy Nanoparticles on Catalytic CO Oxidation. J. Am. Chem. Soc. 2017, 139, 8846-8854. [CrossRef]

39. Reina, T.R.; Megías-Sayago, C.; Florez, A.P.; Ivanova, S.; Centeno, M.Á.; Odriozola, J.A. H ${ }_{2}$ oxidation as criterion for PrOx catalyst selection: Examples based on Au-CoOx-supported systems. J. Catal. 2015, 326, 161-171. [CrossRef]

40. Yung, M.M.; Zhao, Z.; Woods, M.P.; Ozkan, U.S. Preferential oxidation of carbon monoxide on $\mathrm{CoOx}_{2} / \mathrm{ZrO}_{2}$. J. Mol. Catal. A Chem. 2008, 279, 1-9. [CrossRef]

41. Fonseca, J.D.; Ferreira, H.S.; Bion, N.; Pirault-Roy, L.; do Carmo Rangel, M.; Duprez, D.; Epron, F. Cooperative effect between copper and gold on ceria for CO-PROX reaction. Catal. Today 2012, 180, 34-41. [CrossRef]

42. Proaño, L.; Tello, E.; Arellano-Trevino, M.A.; Wang, S.; Farrauto, R.J.; Cobo, M. In-Situ DRIFTS study of two-step $\mathrm{CO}_{2}$ capture and catalytic methanation over $\mathrm{Ru}^{\prime}{ }^{\prime} \mathrm{Na}_{2} \mathrm{O}^{\prime \prime} / \mathrm{Al}_{2} \mathrm{O}_{3}$ Dual Functional Material. Appl. Surf. Sci. 2019, 479, 25-30. [CrossRef]

43. Jhalani, A.; Schmidt, L.D. Preferential CO oxidation in the presence of $\mathrm{H}_{2}, \mathrm{H}_{2} \mathrm{O}$ and $\mathrm{CO}_{2}$ at short contact-times. Catal. Lett. 2005, 104, 103-110. [CrossRef]

44. Tanaka, K.I.; He, H.; Shou, M.; Shi, X. Mechanism of highly selective low temperature PROX reaction of CO in $\mathrm{H}_{2}$ : Oxidation of $\mathrm{CO}$ via HCOO with OH. Catal. Today 2011, 175, 467-470. [CrossRef]

45. Wang, F.; Zhang, L.; Zhu, J.; Han, B.; Zhao, L.; Yu, H.; Deng, Z.; Shi, W. Study on different CeO2 structure stability during ethanol steam reforming reaction over $\mathrm{Ir} / \mathrm{CeO}_{2}$ nanocatalysts. Appl. Catal. A Gen. 2018, 564, 226-233. [CrossRef]

46. Divins, N.J.; Casanovas, A.; Xu, W.; Senanayake, S.D.; Wiater, D.; Trovarelli, A.; Llorca, J. The influence of nano-architectured $\mathrm{CeOx}$ supports in $\mathrm{RhPd} / \mathrm{CeO}_{2}$ for the catalytic ethanol steam reforming reaction. Catal. Today 2015, 253, 99-105. [CrossRef]

47. Li, X.; Fang, S.S.; Teo, J.; Foo, Y.L.; Borgna, A.; Lin, M.; Zhong, Z. Activation and deactivation of Au-Cu/SBA-15 catalyst for preferential oxidation of $\mathrm{CO}$ in $\mathrm{H}_{2}$-Rich Gas. ACS Catal. 2012, 2, 360-369. [CrossRef]

48. Laguna, O.H.; Hernández, W.Y.; Arzamendi, G.; Gandía, L.M.; Centeno, M.A.; Odriozola, J.A. Gold supported on $\mathrm{CuOx} / \mathrm{CeO}_{2}$ catalyst for the purification of hydrogen by the $\mathrm{CO}$ preferential oxidation reaction (PROX). Fuel 2014, 118, 176-185. [CrossRef]

49. Redina, E.A.; Greish, A.A.; Mishin, I.V.; Kapustin, G.I.; Tkachenko, O.P.; Kirichenko, O.A.; Kustov, L.M. Selective oxidation of ethanol to acetaldehyde over $\mathrm{Au}-\mathrm{Cu}$ catalysts prepared by a redox method. Catal. Today 2015, 241, 246-254. [CrossRef] 
50. Wang, J.; Zhong, L.; Lu, J.; Chen, R.; Lei, Y.; Chen, K.; Han, C.; He, S.; Wan, G.; Luo, Y. A solvent-free method to rapidly synthesize $\mathrm{CuO}-\mathrm{CeO}_{2}$ catalysts to enhance their $\mathrm{CO}$ preferential oxidation: Effects of $\mathrm{Cu}$ loading and calcination temperature. Mol. Catal. 2017, 443, 241-252. [CrossRef]

51. Wang, X.; Rodriguez, J.A.; Hanson, J.C.; Gamarra, D.; Martínez-Arias, A.; Fernández-García, M. In Situ Studies of the Active Sites for the Water Gas Shift Reaction over $\mathrm{Cu}-\mathrm{CeO}_{2}$ Catalysts: Complex Interaction between Metallic Copper and Oxygen Vacancies of Ceria. J. Phys. Chem. B 2006, 110, 428-434. [CrossRef]

52. Wang, F.; Büchel, R.; Savitsky, A.; Zalibera, M.; Widmann, D.; Pratsinis, S.E.; Lubitz, W.; Schüth, F. In Situ EPR Study of the Redox Properties of $\mathrm{CuO}-\mathrm{CeO}_{2}$ Catalysts for Preferential CO Oxidation (PROX). ACS Catal. 2016, 6, 3520-3530. [CrossRef]

53. Mallát, T.; Szabó, S.; Petró, J.; Mendioroz, S.; Folgado, M.A. Real and apparent dispersion of carbon supported palladium-cobalt catalysts. Appl. Catal. 1989, 53, 29-40. [CrossRef]

54. Barbato, P.S.; Colussi, S.; Di Benedetto, A.; Landi, G.; Lisi, L.; Llorca, J.; Trovarelli, A. Origin of High Activity and Selectivity of $\mathrm{CuO} / \mathrm{CeO}_{2}$ Catalysts Prepared by Solution Combustion Synthesis in CO-PROX Reaction. J. Phys. Chem. C 2016, 120, 13039-13048. [CrossRef]

55. Schüth, F.; Ward, M.D.; Buriak, J.M. Common Pitfalls of Catalysis Manuscripts Submitted to Chemistry of Materials. Chem. Mater. 2018, 30, 3599-3600. [CrossRef]

56. Cifuentes, B.; Valero, M.; Conesa, J.; Cobo, M. Hydrogen Production by Steam Reforming of Ethanol on Rh-Pt Catalysts: Influence of $\mathrm{CeO}_{2}, \mathrm{ZrO}_{2}$, and $\mathrm{La}_{2} \mathrm{O}_{3}$ as Supports. Catalysts 2015, 5, 1872-1896. [CrossRef]

57. Nagaraja, B.M.; Padmasri, A.H.; Raju, B.D.; Rao, K.S.R. Vapor phase selective hydrogenation of furfural to furfuryl alcohol over Cu-MgO coprecipitated catalysts. J. Mol. Catal. A Chem. 2007, 265, 90-97. [CrossRef]

58. Li, J.; Zhan, Y.; Lin, X.; Zheng, Q. Influence of Calcination Temperature on Properties of $\mathrm{Au} / \mathrm{Fe}_{2} \mathrm{O}_{3}$ Catalysts for Low Temperature Water Gas Shift Reaction. Acta Phys.-Chim. Sin. 2008, 24, 932-938. [CrossRef]

59. Liu, F.; Xiao, Y.; Sun, X.; Qin, G.; Song, X.; Liu, Y. Synergistic catalysis over hollow $\mathrm{CeO}_{2}-\mathrm{CaO}_{-} \mathrm{ZrO}_{2}$ nanostructure for polycarbonate methanolysis with methanol. Chem. Eng. J. 2019, 369, 205-214. [CrossRef]

60. Chen, W.; Ran, R.; Weng, D.; Wu, X.; Zhong, J.; Han, S. Influence of morphology on basicity of $\mathrm{CeO}_{2}$ and its use in 2-chloroethyl ethyl sulfide degradation. J. Rare Earths 2017, 35, 970-976. [CrossRef]

61. Malik, A.S.; Zaman, S.F.; Al-Zahrani, A.A.; Daous, M.A.; Driss, H.; Petrov, L.A. Selective hydrogenation of $\mathrm{CO}_{2}$ to $\mathrm{CH}_{3} \mathrm{OH}$ and in-depth DRIFT analysis for $\mathrm{PdZn} / \mathrm{ZrO}_{2}$ and $\mathrm{CaPdZn} / \mathrm{ZrO}_{2}$ catalysts. Catal. Today 2019, in press. [CrossRef]

62. Zhou, W.; Ma, Z.; Guo, S.; Wang, M.; Wang, J.; Xia, M.; Jia, L.; Hou, B.; Li, D.; Zhao, Y. Comparative study of $\mathrm{CO}$ adsorption on zirconia polymorphs with DRIFT and transmission FT-IR spectroscopy. Appl. Surf. Sci. 2018, 427, 867-873. [CrossRef]

63. Agarwal, S.; Mojet, B.L.; Lefferts, L.; Datye, A.K. Ceria Nanoshapes-Structural and Catalytic Properties. In Catalysis by Materials with Well-Defined Structures; Elsevier: Amsterdam, The Netherlands, 2015; pp. 31-70.

64. Leba, A.; Davran-Candan, T.; Önsan, Z.I.; Yildirim, R. DRIFTS study of selective CO oxidation over $\mathrm{Au} / \gamma \mathrm{Al}_{2} \mathrm{O}_{3}$ catalyst. Catal. Commun. 2012, 29, 6-10. [CrossRef]

65. Fernández-García, S.; Collins, S.E.; Tinoco, M.; Hungría, A.B.; Calvino, J.J.; Cauqui, M.A.; Chen, X. Influence of $\{111\}$ nanofaceting on the dynamics of $\mathrm{CO}$ adsorption and oxidation over $\mathrm{Au}$ supported on $\mathrm{CeO}_{2}$ nanocubes: An operando DRIFT insight. Catal. Today 2019, 336, 90-98. [CrossRef]

66. Gamarra, D.; Martínez-Arias, A. Preferential oxidation of $\mathrm{CO}$ in rich $\mathrm{H}_{2}$ over $\mathrm{CuO} / \mathrm{CeO}_{2}$ : Operando-DRIFTS analysis of deactivating effect of $\mathrm{CO}_{2}$ and H2O. J. Catal. 2009, 263, 189-195. [CrossRef]

67. Moretti, E.; Lenarda, M.; Storaro, L.; Talon, A.; Frattini, R.; Polizzi, S.; Rodríguez-Castellón, E.; Jiménez-López, A. Catalytic purification of hydrogen streams by PROX on Cu supported on an organized mesoporous ceria-modified alumina. Appl. Catal. B Environ. 2007, 72, 149-156. [CrossRef]

68. Polster, C.S.; Nair, H.; Baertsch, C.D. Study of active sites and mechanism responsible for highly selective $\mathrm{CO}$ oxidation in $\mathrm{H}_{2}$ rich atmospheres on a mixed $\mathrm{Cu}$ and Ce oxide catalyst. J. Catal. 2009, 266, 308-319. [CrossRef]

69. Suzuki, Y.; Hayakawa, K.; Fukuhara, C.; Watanabe, R.; Kawasaki, W. A novel nickel-based structured catalyst for $\mathrm{CO}_{2}$ methanation: A honeycomb-type $\mathrm{Ni} / \mathrm{CeO}_{2}$ catalyst to transform greenhouse gas into useful resources. Appl. Catal. A Gen. 2016, 532, 12-18.

70. Le, T.A.; Kim, M.S.; Lee, S.H.; Kim, T.W.; Park, E.D. $\mathrm{CO}$ and $\mathrm{CO}_{2}$ methanation over supported Ni catalysts. Catal. Today 2017, 293-294, 89-96. [CrossRef] 
71. Sahoo, D.R.; Vajpai, S.; Patel, S.; Pant, K.K. Kinetic modeling of steam reforming of ethanol for the production of hydrogen over $\mathrm{Co} / \mathrm{Al}_{2} \mathrm{O}_{3}$ catalyst. Chem. Eng. J. 2007, 125, 139-147. [CrossRef]

72. Cifuentes, B.; Bustamante, F.; Cobo, M. Data for: Single and dual metal oxides as promising supports for carbon monoxide removal from an actual syngas. Mendeley Datasets 2019, 1-10. [CrossRef]

(C) 2019 by the authors. Licensee MDPI, Basel, Switzerland. This article is an open access article distributed under the terms and conditions of the Creative Commons Attribution (CC BY) license (http://creativecommons.org/licenses/by/4.0/). 